INDIAN INSTITUTE OF MANAGEMENT AHMEDABAD

\title{
IIMA
}

Working Paper

\section{Pre-packs in the Indian Insolvency Regime}

M. P. Ram Mohan

Vishakha Raj

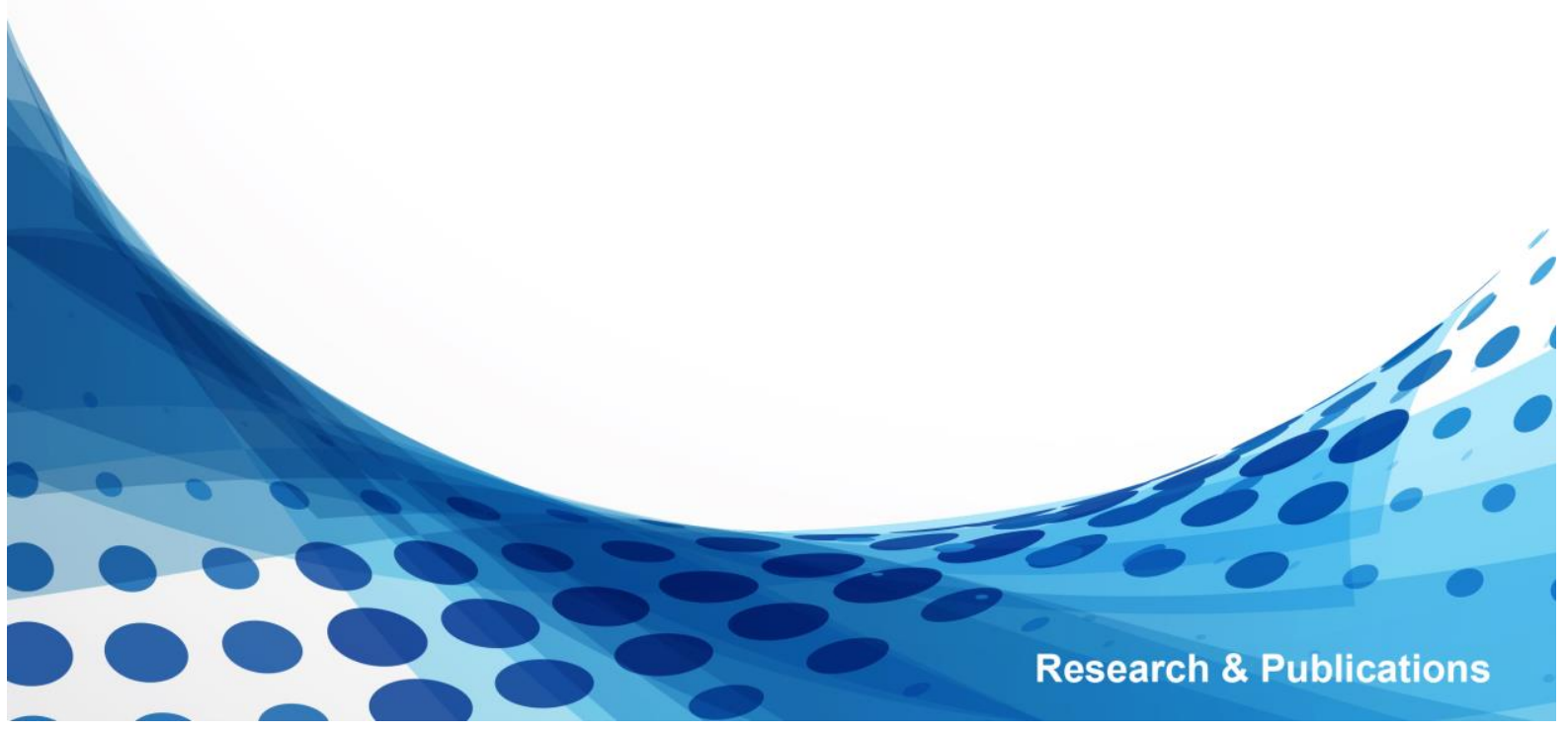




\title{
Pre-packs in the Indian Insolvency Regime
}

\author{
M. P. Ram Mohan \\ Vishakha Raj
}

August 2020

The main objective of the working paper series of the IIMA is to help faculty members, research staff and doctoral students to speedily share their research findings with professional colleagues and test their research findings at the pre-publication stage. IIMA is committed to maintain academic freedom. The opinion(s), view(s) and conclusion(s) expressed in the working paper are those of the authors and not that of IIMA. 


\title{
Pre-packs in the Indian Insolvency Regime
}

\author{
M P Ram Mohan* \& Vishakha Raj**
}

\begin{abstract}
:
Pre-packaging allows a distressed company to negotiate a plan with its creditors and a purchaser before entering formal insolvency proceedings. By allowing the terms of a plan to be negotiated before formal proceedings, pre-packs provide a quick and discreet way of completing the insolvency resolution process. The speed and confidentiality offered by prepacks have made them prevalent in the United Kingdom and the United States, however, these advantages come with trade-offs. Creditors' voting rights under the regular insolvency resolution process are circumvented by the pre-pack process. The US has two pre-pack processes, one that requires creditor approval and another which does not. In the UK and the US, there has been opposition to regulating pre-packs that do not need creditor approval because reforms that increase creditor participation will reduce the speed associated with such pre-packs. In India, pre-packs have not evolved through the present regime as it does not allow for the assets of a debtor to be sold without its creditors' approval. The Insolvency and Bankruptcy Board of India is considering introducing pre-packs in the Indian regime and faces unique challenges because of some of the features in India's insolvency regime. Insolvency law in India prohibits the participation of a company's directors and creditors in the pre-pack process. Indian insolvency law also has broad avoidance provisions which can complicate the implementation of pre-packs. This paper discusses these challenges and uses the experience of the UK and the US to suggest a framework for the introduction of pre-packaged insolvency in India. After evaluating the pre-pack regimes in the UK and the US, we conclude that it would be optimal for India to retain creditor protections and require creditor approvals in its pre-pack regime. This would ensure that pre-packs can be discreetly implemented and also avoids the disenfranchisement of creditors.
\end{abstract}

\footnotetext{
* Associate Professor, Strategy Area, Indian Institute of Management Ahmedabad (mprmohan@iima.ac.in)

**Researcher, Strategy Area, Indian Institute of Management Ahmedabad.

We are grateful to Laura Napoli Coordes, Adrian J. Walters, Christoph Henkel, Andrew Dawson, thanks to Research and Publication Area of IIMA for funding the project and Praachi Misra for review comments. This paper is submitted to the Third International \& Comparative Insolvency Symposium scheduled during 12-13 November 2020. All errors are our own.
} 


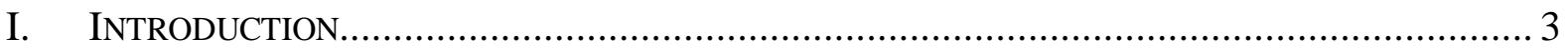

II. A COMPARATIVE OVERVIEW OF INSOLVENCY LAWS IN THE UK, THE US, AND INDIA......... 6

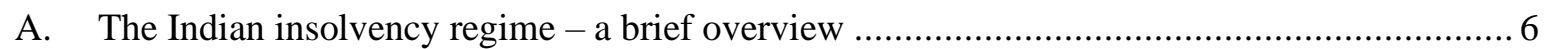

B. Key comparisons between the insolvency regimes of the US, the UK, and India.................. 8

C. Challenges to introducing pre-pack in India.................................................................. 10

1. The IBC's treatment of the incumbent management's participation in the insolvency resolution

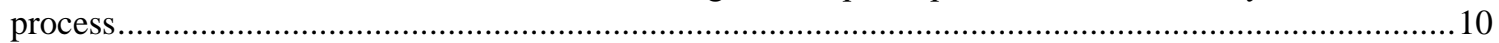

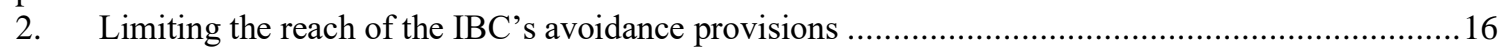

III. IMPLEMENTATION OF PRE-PACKAGING IN THE UK AND THE US ................................ 18

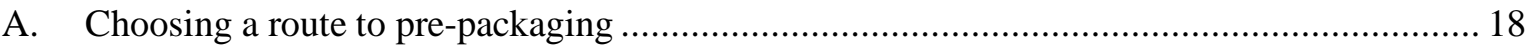

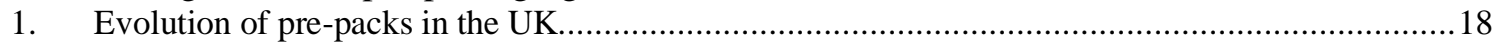

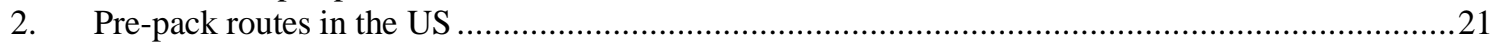

B. Regulating pre-packs: assessing the adequacy of current reformative trends ........................ 25

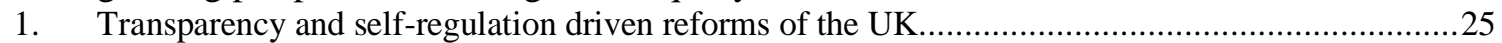

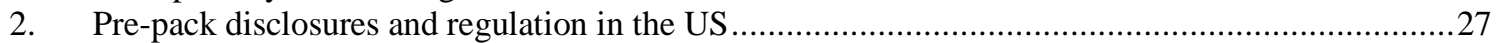

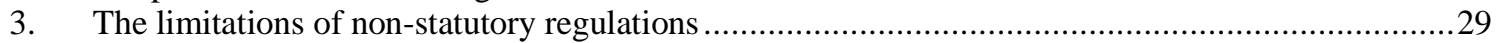

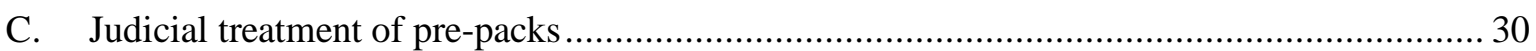

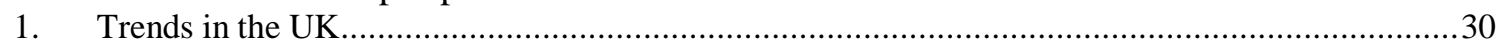

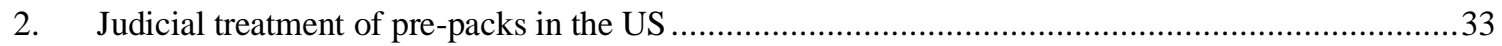

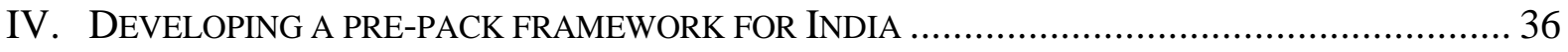

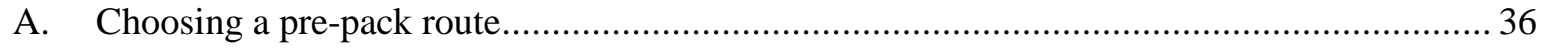

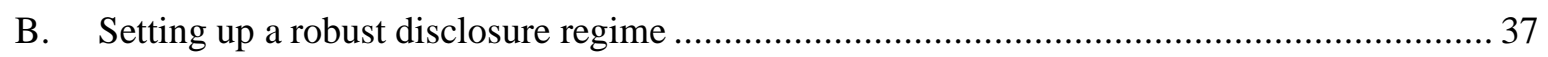

C. Protection of creditors rights and the limits of judicial oversight ........................................... 39

D. Compromising on speed for more stability and fairness .................................................... 42

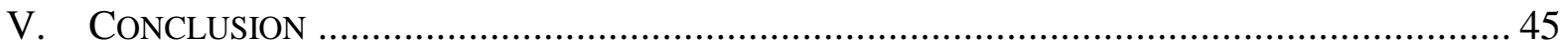




\section{INTRODUCTION}

The Insolvency and Bankruptcy Board of India is in the process of introducing a pre-packaging regime in India. ${ }^{1}$ In a pre-packaged insolvency (pre-pack), a troubled company and its creditors negotiate the terms of an insolvency resolution plan prior to the commencement of the formal insolvency process. ${ }^{2}$ The negotiated resolution plan is then implemented soon after the formal proceedings begin, it often involves the sale of all or a substantial portion of the company's business. Pre-packaged insolvency seems to be a natural step in the evolution of insolvency regimes. Many countries, including the United Kingdom (UK) ${ }^{3}$ and the United States (US), ${ }^{4}$ allow pre-packaged insolvencies. While it is difficult to determine the exact point at which prepack negotiations begin, they are normally carried out when the corporate debtor is under some financial or economic distress. ${ }^{5}$

Pre-packs offer unique advantages when compared to the regular insolvency resolution process. Most of these advantages stem from a pre-pack's ability to reduce the time spent by a company in formal insolvency proceedings. This is made possible by negotiating the terms of a plan before an insolvency application is filed. ${ }^{6}$ This may seem counterintuitive because one of the key functions of modern insolvency law is to give creditors a space to bargain and come to an agreement about the future of a distressed company. ${ }^{7}$ However, the costs of solely relying on the traditional insolvency resolution process are now coming to the forefront of discussions. Longer and more public insolvency proceedings are likely to spook the market and reduce the

\footnotetext{
${ }^{1}$ Special insolvency resolution framework for MSMEs at advanced stage: IBBI chief, ECONOMIC TIMES (Jul. 26, 2020), https://economictimes.indiatimes.com/small-biz/sme-sector/special-insolvency-resolution-frameworkfor-msmes-at-advanced-stage-ibbi-chief/articleshow/77180706.cms;

Notice, Ministry of Corporate Affairs, (April 2019), https://ibbi.gov.in/webfront/Notice\%20for\%20inviting\%20public\%20comments\%20on\%20Code.pdf. See FE Bureau, Pre-packaged insolvency resolution: Govt. seeks stakeholder comments, FINANCIAL EXPRESS (Apr. 17, 2019), financialexpress.com/economy/pre-packaged-insolvency-resolution-govt-seeks-stakeholdercomments/1550354/; Paul Williams, Pre-packaged insolvency: Process should help achieve overarching objectives of the IBC, FINANCIAL EXPRESS (May 08, 2019), https://www.financialexpress.com/opinion/prepackaged-insolvency-process-should-help-achieve-the-overarching-objectives-of-the-ibc/1571593/.

${ }^{2}$ VANessa FinCh \& DaVid Milman, Corporate Insolvency LaW: PerspeCtives AND Principles 372, 373 $\left(3^{\text {rd }}\right.$ ed., 2017).

3 Venessa Finch, Corporate Insolvency Law: Perspectives and Principles (2 ${ }^{\text {nd }}$ ed., 2009), 453.

${ }^{4} 11$ U.S.C. $\S 1125(\mathrm{~g})(2020)$

${ }_{6}^{5}$ Finch \& Milman, supra, at 371.

6 Lorraine Conway, Pre-pack administrations, House of COMmOns Library, 3, (Dec. 16, 2019), https://commonslibrary.parliament.uk/research-briefings/sn05035/

${ }^{7}$ Bo Xie, Comparative insolvency Law: The Pre-Pack Approach in Corporate Rescue 8-9 (2016); Thomas H. Jackson, Bankruptcy, Non-Bankruptcy Entitlements, and the Creditors' Bargain, 91 YALE L.J. 857, 861-62 (1982).
} 
value of the company, further, it becomes more difficult to raise finance when a company is undergoing a formal insolvency resolution process, making day to day activities and trading uncertain. ${ }^{8}$ Shorter insolvency proceedings through pre-packs have preserved employment and help maximise the value of the firm. ${ }^{9}$ A study on Dutch insolvency practice found that prepacks increased employment retention in a company notwithstanding its level of financial distress prior to the bankruptcy filing. ${ }^{10}$ The clandestine nature of pre-packs ${ }^{11}$ also allows a company to retain its reputation with its suppliers, customers, and investors. ${ }^{12}$ Through their speed and confidentiality, pre-packs effectively reduce the indirect costs associated with the insolvency resolution process. ${ }^{13}$

While the advantages of pre-packs make it an attractive option for distressed companies, prepacks that can be effected without creditors' approval and disenfranchise unsecured creditors. In such cases, the company's unsecured creditors are usually left without any notice of the company's distress until the formal insolvency proceedings are filed. This effectively removes their ability to participate in the negotiations which result in the sale of the company's assets. ${ }^{14}$ Though pre-packs often pay suppliers the full amount of their claim (mainly to avoid negotiations with them $)^{15}$, these suppliers will continue their commercial relationship with the company without notice of its distress and increase their exposure. ${ }^{16}$ Pre-packs do away with the open bargaining process that is facilitated by the regular insolvency process. Creditors who were not a part of pre-pack negotiations cannot influence the course of a pre-pack, even after formal proceedings commence. This is because the insolvency professional who participates in pre-pack negotiations by advising the debtor or creditors ${ }^{17}$ is appointed as the resolution professional after the formal insolvency proceedings are filed. ${ }^{18}$ This ensures that the terms of

\footnotetext{
${ }^{8}$ Sofia Ellina, Administration and CVA in corporate insolvency law: pursuing the optimum outcome, 30 INTERNATIONAL INSOLVENCY AND COMMERCIAL LAW REVIEW, 180, 189-90 (2019).

9 Teresa Graham, Graham Review into Pre-pack Administration, Gov.UK, 26, (Jun. 16 2014) https://www.gov.uk/government/publications/graham-review-into-pre-pack-

administration\#: : :text $=$ The $\% 20$ report $\% 20$ was $\% 20$ carried $\% 20$ out, Government $\% 20$ response $\% 20$ to $\% 20$ the $\% 20 \mathrm{R}$ eview. [Henceforth Graham Report]; Finch, supra note 3, at 456-457; Peter Walton, Pre-packin' in the UK, 18 INT. INSOLVENCY REV.. 85, 92 (2009).

${ }^{10}$ Henrick Albers et al., Does Pre-Packed Bankruptcy Create Value? An Empirical Study of Post-Bankruptcy Retention in the Netherlands, 28 InT. InSOLVENCY REV. 320, 336-37 (2019).

${ }^{11}$ XIE, supra note 7, at 147. FINCH \& Milman, supra note 2, at 404,

12 Brian L. Betker, An Empirical Examination of Bre-packaged bankruptcy, 24 FIN. MGMT. 3, 7-8 (1995); See

XIE, supra note 7, at 96-97; FINCH \& MiLmAN, supra note 2, at 375.

13 Betker, supra, at 3.

${ }^{14}$ FINCH \& MiLmAN, supra note 2, at 387.

${ }^{15}$ FINCH \& Milman, supra note 2, at 372.

${ }^{16} \mathrm{Id}$. at 379; Walton, supra note 9 , at 87.

${ }^{17}$ XIE, supra note 7 , at 100-10.

${ }^{18}$ FinCH \& Milman, supra note 2, at 397; Walton, supra note 9, at 91-92.
} 
the negotiated pre-pack translate into a formal and binding resolution plan under the relevant insolvency law. ${ }^{19}$ While this practice is beneficial to those privy to the pre-pack negotiations, it reduces the independence usually expected of the resolution professional. ${ }^{20}$

The UK and the US have employed different approaches to regulating pre-packs and the challenges to fairness and transparency which they pose. The nature of these difficulties and their extent differ based on the type of pre-pack regime in place. In the UK, a pre-pack can be completed without creditor approval, or even consultation. ${ }^{21}$ The pre-pack's ability to circumvent creditors' procedural voting rights makes unsecured creditors vulnerable stakeholders in the process. ${ }^{22}$ In the US, pre-packs can be effected through two routes, one requires creditors' approval and the other does not. Studying these pre-pack regimes will help prepare India for the challenges its pre-pack regime is likely to face and inform the design of its pre-packaging law.

India's interest in introducing pre-packs puts it in a unique position. Since pre-packs are not prevalent in the status quo in India, law makers can substantially direct how pre-packs will evolve and operate. India also has the benefit of the UK's and US's experience with prepackaging and has a range of measures from which it can piece together the framework of its pre-pack regime. India's insolvency regime has distinct features, some of these features make the insolvency regime conducive to pre-packs while others make the introduction of pre-packs more challenging. Two such challenges are posed by the insolvency law's prohibition of promoters' and directors' participation in the insolvency resolution process and its broad avoidance provisions. Section II of the paper discusses these two issues in detail after providing a comparative overview of the insolvency regimes in India, the UK, and the US. Section III evaluates the pre-pack regimes of the UK and the US using three themes - the route to pre-packaging, modes of regulation, and judicial engagement. In Section IV, insights from Section III are used to recommend the optimal route for the introduction of pre-packs in India and identify important safeguards to ensure the Indian pre-pack regime remains fair and transparent.

\footnotetext{
${ }^{19}$ XIE, supra note 2, at 78.

${ }^{20}$ Id.; FinCH \& Milman, supra note 2, at 397; Mark Wellard \& Peter Walton, A Comparative Analysis of Anglo-Australian Pre-packs: Can the Means be Made to Justify the Ends?, 21 INT. INSOLVENCY REV. 143,147 (2012); Sandra Frisby, A preliminary assessment of pre-packaged administrations, Report to the Association of Business Recovery Professionals 65 (2007).

${ }^{21}$ FINCH \& MiLmAN, supra note 2, at 377; Walton, supra note 9, at 87.

${ }^{22}$ Walton, supra note 9, at 87; Wellard \& Walton, supra note 20, at 157.
} 


\section{A COMPARATIVE OVERVIEW OF INSOLVENCY LAWS IN THE UK, THE US, AND INDIA}

\section{A. The Indian insolvency regime $-\mathbf{a}$ brief overview}

The Insolvency and Bankruptcy Code, 2016 (IBC) contains the Indian insolvency regime. The objectives of the IBC are enumerated in its Preamble. ${ }^{23}$ The IBC aims to maximise the value of the debtor's assets, promote entrepreneurship, and the availability of credit and balance the interests of all the stakeholders involved in the resolution process. ${ }^{24}$ The IBC also enshrines the objective of completing the insolvency resolution process in a time bound manner, prepacks would help further this objective of the IBC. The IBC bears similarities and differences to the UK and US insolvency regimes. The following discussion examines features of the IBC which are unique to the Indian insolvency regime, and then compares the insolvency laws of the three jurisdictions. Since insolvency laws in the UK and the US shaped their experiences with pre-packs and regulatory challenges associated with them, comparing the insolvency laws of these two jurisdictions with those of India will shed light on the types of challenges India is likely to face after introducing pre-packs. It will also help identify any pre-emptive steps that can be taken to mitigate these challenges.

The IBC divides a corporate debtor's creditors into financial creditors and operational creditors, this demarcation has an important bearing on who decides the future of the corporate debtor. ${ }^{25}$ Only financial creditors, or those who disbursed money to the debtor for a consideration of the time value of money constitute the Committee of Creditors or the (CoC) ${ }^{26}$ The $\mathrm{CoC}$ evaluates and approves resolution plans submitted for the reorganisation of the corporate debtor. ${ }^{27}$ Members of the $\mathrm{CoC}$ cast votes in proportion to the debts owed to them by the corporate debtor, a plan needs to be approved by at least 66 percent of the CoC's votes. ${ }^{28}$ The National Company Law Appellate Tribunal (NCLT) as the Adjudicating Authority under the IBC. ${ }^{29}$ The NCLT is in charge of approving resolution plans and ensuring that they are compliant with the IBC

\footnotetext{
${ }^{23}$ Insolvency and Bankruptcy Code, No. 31, Acts of Parliament, 2016, Preamble [Henceforth IBC]

${ }^{24} I d$.

${ }^{25} I d . \S 21$.

${ }^{26} I d . \S 5(8)$

${ }^{27} I d . \S(30)(4)$

${ }^{28} I d . \S \S 5(28), 30(4)$

${ }^{29}$ Id. § 5(1)
} 
and other laws. ${ }^{30}$ Persons aggrieved by the decision of the NCLT can approach the National Company Law Appellate Tribunal (NCLAT). ${ }^{31}$ The appeals from NCLAT decisions lie with the Supreme Court of India. ${ }^{32}$

Operational creditors comprise persons such as employees and trade creditors. ${ }^{33}$ These are persons whose relationship with the corporate person is based on the provision of goods or services. Operational creditors and financial creditors are both allowed to file an insolvency application against a company if they are owed a sum exceeding INR $10,000,000^{34}$ (equivalent to $1,33,458.07$ US \$). However, a corporate debtor needs to be given a notice of ten days to repay the operational debt and has the ability to dispute an operational debt. ${ }^{35}$ This is different from the procedure applied in case of an application filed by a financial creditor. The NCLT is bound to admit the application of a financial creditor provided that a default has occurred. ${ }^{36}$

Operational creditors are granted certain protections under the IBC in lieu of the right to vote on resolution plans. Resolution plans are required to provide operational creditors with the amount they would have gotten in the event of a liquidation or the amount they would have gotten if the money distributed under the plan were distributed as per the hierarchy of the liquidation waterfall (whichever of the two is higher). ${ }^{37}$ Additionally, Regulation 38 of the Insolvency Resolution Regulations requires payments under the plan to operational creditors to be made in priority to payments to financial creditors. ${ }^{38}$ Having traversed these important features of the Indian insolvency regime, we now turn to the insolvency regimes of the UK and the US. The differences between the insolvency regimes of India, the UK and the US need to be identified to fully appreciate the extent to which these insights can be applied to India.

\footnotetext{
${ }^{30} I d . \$ 30$

${ }^{31} I d . \S 61(1)$

${ }^{32}$ Companies Act, No. 18, Acts of Parliament, $2013 \S 423$.

${ }^{33}$ IBC, supra note $23, \S \S 5(20)-(21)$

${ }^{34}$ Id. § 4; See Notification, 2020, S.O. 1205 (E), https://ibbi.gov.in//uploads/legalframwork/48bf32150f5d6b30477b74f652964edc.pdf

${ }^{35}$ IBC, supra note $23, \S \S 8-9$

${ }^{36}$ Id. $\S 7$, See Innoventive Industries v. ICICI Bank (2018) 1 SCC 407.

${ }^{37}$ IBC, supra note $23, \S 30(3)(\mathrm{b})$.

${ }^{38}$ Insolvency and Bankruptcy Board of India (Insolvency Resolution Process for Corporate Persons) Regulations, 2016, IBBI/2016-17/GN/REG004, https://ibbi.gov.in//uploads/legalframwork/2020-04-27-114849-uqs43ca9a1f1f849a43f3290c4b9512d0c863.pdf.
} 


\section{B. Key comparisons between the insolvency regimes of the US, the UK, and India}

The substantial insolvency laws of the UK and the US are contained in the Insolvency Act, $1986^{39}$ and the and Title 11 of the US Code ${ }^{40}$ (US Bankruptcy Code) respectively. Chapter 11 of Title 11 in the US governs corporate reorganisation and is the counter part of the corporate insolvency resolution process under the IBC. Chapter 11 contains one of the two pre-pack routes in the US, the other is contained in section 363 of the US Bankruptcy Code. The UK Insolvency Act provides for three routes to formal rescue which include, company voluntary agreements (CVAs), administrative receivership, and administration. ${ }^{41}$ Most pre-packs in the UK are affected through administration which is governed by Schedule B1 of the Insolvency Act. $^{42}$

There are some important similarities between India's and the UK's insolvency laws. These include similarities in the treatment of shareholders during the insolvency process and the role of the resolution professional. In India and in England, shareholders' claims are not considered during a company's insolvency resolution process and administration respectively. ${ }^{43}$ This is different form the position in the US where shareholders are subordinate to creditors but remain an interested party nonetheless. ${ }^{44}$ In the US, a reorganisation plan needs to be approved by twothirds of shareholders under Chapter 11 in addition to being approved by creditors. ${ }^{45}$ Under Chapter 11, a bankruptcy trustee (who is roughly analogous to the administrator in the UK and the resolution professional under the IBC) ${ }^{46}$ need not be appointed in every Chapter 11 case. $^{47}$ A bankruptcy trustee is also not a pre-requisite for a section 363 pre-pack. ${ }^{48}$ Section 363 sales can be affected by the debtor or the bankruptcy trustee if one is appointed. ${ }^{49}$ However, in the UK and India, administrators and resolution professionals are a mandatory and indispensable

\footnotetext{
${ }^{39}$ Insolvency Act 1986, c. 45 (UK).

40 11 U.S.C. (2018)

${ }^{41}$ See Insolvency Act, supra, parts I-III.

${ }^{42}$ In re Transbus Ltd [2004] EWHC 932 (Ch); Frisby, supra note 20, at 15-16, XIE, supra note 7, at 26; FINCH \& MILMAN, supra note 2, at 375.

${ }^{43}$ Shareholder approval is deemed to be given under $\S 30(2)$ of the IBC. See XIE, supra note 7, at 182 for the English and US positions.

${ }^{44}$ XIE, supra note 7 , at 182

${ }^{45} I d$.

${ }^{46}$ See, Himani Singh, Pre-packaged insolvency in India: Lessons from the USA \& UK, Harvard Bankruptcy Round Table, 3, 12, (Apr. 24, 2020), https://blogs.harvard.edu/bankruptcyroundtable/tag/himani-singh/.

${ }^{47}$ Bankruptcy Basics - How Chapter 11 works, US COURTS, https://www.uscourts.gov/servicesforms/bankruptcy/bankruptcy-basics/chapter-11-bankruptcy-basics.

${ }^{48}$ Id.; 11 U.S.C. $§ 363(\mathrm{~b})(1)$; Alfonso Nocilla, Asset sales and secured creditor control in restructuring: A comparison of the US, UK, and Canadian models, 26 INT. INSOLVENCY REV., 60, 72 (2017).

${ }^{49}$ Nocilla, supra, at 75; XIE, supra note 7, at 205.
} 
part of administration and the insolvency resolution processes process respectively. Unlike Schedule B1 and section 363, the IBC does not empower a resolution professional to sell the assets of a corporate debtor without the authorisation of creditors. The resolution professional has the power to manage the affairs of the company and has 'control and custody' over the debtor's assets but this does not extend to disposing of them. ${ }^{50}$ This limitation, may be the reason why India has not seen the spontaneous evolution of pre-packs.

While substantial similarities exist between the Indian and UK insolvency regimes, there are also important differences. Under the IBC regime, the NCLT (the adjudicating authority) plays an active role in overseeing the insolvency process and approving the insolvency resolution plan after it has been accepted by the $\mathrm{CoC}$. This is different from the largely deferential trend in the UK where courts seldom interfere with commercial decisions of an administrator. Additionally, in the UK, it is possible for an administrator to be appointed out of court, after which, the administration process is then implemented and completed without court supervision. The role played by the NCLT in India is similar to that of the bankruptcy court (under the US Bankruptcy Code) which needs to approve Chapter 11 reorganisation plans. Under Section 30 of the IBC, there are statutory requirements which an insolvency resolution plan must adhere to in order to be confirmed by the NCLT. This process of plan confirmation under section 30 has been compared to section 1129 of the US Bankruptcy Code which also contains a checklist of conditions a plan must meet before a bankruptcy court can confirm it. ${ }^{51}$

The Indian regime thus bears important similarities to the US and UK regimes but is also identifiably different from each of them, for instance in its approach to dividing creditors into operational and financial creditors. The Indian insolvency regime is thus capable of adopting either jurisdiction's approach to pre-pack regimes or even a mixture of the features of both regimes. An important difference between the Indian regime and those in the UK and the US is the IBC's prohibition on related parties of a company buying back their company's assets through the insolvency resolution process. The prevalence of pre-pack sales to connected parties (directors, shadow directors, and promoters) in the UK and the US casts doubts on whether the IBC can maintain its strict policy against connected party sales after pre-packs are

\footnotetext{
${ }^{50}$ Vinod Kothari \& Sikha Bansal, Role of Insolvency Professionals, VINOD KOTHARI 69, http://vinodkothari.com/wp-content/uploads/2019/06/Role-of-IP-in-CIRP.pdf.

${ }^{51}$ C. Scott Pryor, Good news for secured in India: Supreme Court confirms priority of secured claims (and more), AM. B. InST. J. 26, 26 (2020).
} 
introduced. This issue, along with the effect of the IBC's broad avoidance provisions have been discussed below.

\section{Challenges to introducing pre-pack in India}

\section{The IBC's treatment of the incumbent management's participation in the insolvency resolution process}

When the IBC was first introduced and brought into force in 2016, there was no prohibition on promoters being resolution applicants. The 2016 law defined a resolution applicant as 'any person' who submits a resolution plan with respect to a corporate debtor. ${ }^{52}$ Section 29A was added through the first amendment to the IBC in $2018 .{ }^{53}$ The rationale behind this amendment was that unscrupulous persons were using the IBC to regain control of companies that they had mismanaged and brought to the stage of insolvency. ${ }^{54}$ However, this approach runs into the same problem of excluding all promoters and directors, irrespective of whether their management style contributed to the downfall of a company. A 2014 study in the UK revealed that most pre-packs were filed for companies that failed due to market conditions such as an increase in the cost of raw materials and changes in currency exchange rates. ${ }^{55}$ Thus, sales to connected parties can be justified not only because they are often the only ones who are willing to purchase the business as a whole, but also because they are not always responsible for a company's distress.

The Bankruptcy Law Review Committee's Report, 2015 (BLRC Report) ${ }^{56}$ containing the design of the IBC, originally encouraged promoters to buy back their distressed corporation and have a second chance at running them. ${ }^{57}$ The report also distinguished between the

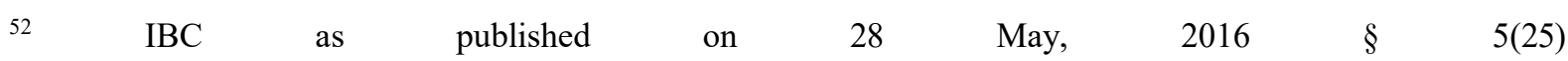
https://ibbi.gov.in//webadmin/pdf/legalframwork/2017/Jul/IBC\%202016.pdf.

${ }_{53}^{53}$ Insolvency and Bankruptcy Code (Amendment) Act, No. 8, Acts of Parliament, $2018 \S 5$.

54 Statement of Objects and Reasons, Insolvency and Bankruptcy Code (Amendment) Bill, 2017, 5, https://www.prsindia.org/sites/default/files/bill files/Insolvency $\% 20$ and $\% 20$ Bankruptcy $\% 20$ Code $\% 20 \mathrm{Amendm}$ ent $\% 20$ Bill $\% 202017 . p d f$

${ }^{55}$ Peter Walton \& Chris Umfrevile, Pre-pack Empirical Research: Characteristic and Outcome Analysis of Prepack Administration, University of Wolverhampton, Gov.UK (Jun. 26, 2014), https://www.gov.uk/government/publications/graham-review-into-pre-packadministration\#: :text=The $\% 20$ report $\% 20$ was $\% 20$ carried $\% 20$ out, Government $\% 20$ response $\% 20$ to $\% 20$ the $\% 20 \mathrm{R}$ eview. This report was prepared to assist the Graham Review of pre-packs in 2014.

${ }^{56}$ Ministry of Finance, Report of the Bankruptcy Law Reforms Committee - Volume I: Rationale and Design (November 2015), https://ibbi.gov.in/BLRCReportVol1_04112015.pdf [Henceforth BLRC Report]

${ }^{57}$ BLRC Report, supra, at 13.
} 
malfeasance of a promoter and business failure. ${ }^{58}$ Though the distinction was made in the context of a promoter's personal liability for business failure, it can be applied to giving them a second chance at running their business as well. The BLRC Report further stated that some ventures are bound to fail and this failure cannot be attributed to any malfeasance. The limited liability corporation encourages some amount of risk taking, this is an integral part of any business. Sometimes, these risks do not pay off, this in itself does not mean that they warrant any legal censure..$^{59}$

\section{Prohibition on connected party participation in the insolvency resolution process}

India's current position on the incumbent management and promoters' participation in the insolvency resolution plan is very different from what was envisioned by the BLRC Report. Section $29 \mathrm{~A}^{60}$ of the IBC prohibits promoters and managers of companies (connected parties) that have non-performing assets from being resolution applicants, this effectively prohibits the promoters and directors of a company undergoing the insolvency resolution process from submitting a resolution plan. The IBC's current position on the issue not only differs from the IBC's original position in 2016 but also the approach of the UK and the US. In the US, a corporate debtor is encouraged to submit plans for its own reorganisation. Once an insolvency application is filed under Chapter 11, the corporate debtor has the exclusive right to submit a plan for a period of the 120 days. ${ }^{61}$ Further, the US' 'debtor in possession' bankruptcy regime, ${ }^{62}$ allows the incumbent management of the company retain control over the corporate debtor and it is not replaced by persons like the resolution professional or the administrator (as in India and the UK). ${ }^{63}$ India and the UK have a 'creditor in possession' regime and there are some limitarions on connected party participation in the UK as well. Under the UK Insolvency Act, directors of companies that have gone through liquidation are prevented from being on the board of another company which has the same or similar name. ${ }^{64}$ However, this prohibition applies to very specific form of pre-pack sale and has not significantly affected pre-pack sales to connected parties which comprise two-thirds of pre-pack sales. ${ }^{65}$

\footnotetext{
${ }^{58}$ Id. 22-24.

${ }^{59} \mathrm{Id}$.

${ }^{60}$ IBC, supra note $23, \S 29-\mathrm{A}$.

${ }^{61} 11$ U.S.C. $\$ 1121(\mathrm{~b})$

${ }^{62}$ Bankruptcy Basics - How Chapter 11 works, US COURTS, https://www.uscourts.gov/servicesforms/bankruptcy/bankruptcy-basics/chapter-11-bankruptcy-basics.

${ }^{63}$ Nocilla, supra note 48 , at 71.

${ }^{64}$ Wellard \& Walton, supra note 20, at 141, 155.

${ }^{65} I d$.
} 
Under the IBC's regulations, connected parties are also prohibited from participating in a compromise or agreement involving the distressed company after a liquidation order is passed under the IBC. ${ }^{66}$ Even if a secured creditor wants to realise the value of their security without relinquishing it to the liquidation estate, they are barred from selling their secured interest to a promoter or the incumbent management. ${ }^{67}$ Under the present IBC regime, a pre-pack sale to a connected party would be prohibited even if it has the sanction of all the secured and unsecured creditors by virtue of the statutory provisions of the IBC. The scepticism associated with the incumbent management of an insolvency company also extends to their participation in insolvency proceedings, even if they are not bidding to buy back their company. The case of Chitra Sharma v. Union of India, ${ }^{68}$ decided by the Supreme Court of India, can be used to animate the Indian insolvency regime's stance on promoters participating in the resolution of their distressed companies.

In Chitra Sharma, the Supreme Court did not allow the corporate debtor to enter into a master restructuring agreement (MRA) which was acceptable to all of its creditors. ${ }^{69}$ Under the MRA, the company would have had to sell some of its assets in order to complete ongoing projects. The court's decision was informed by two considerations, both of which operate independently. One of these considerations was the addition of homebuyers to the category of 'financial creditors' under the IBC through an amendment in $2018 .^{70}$ Since this amendment was made after the insolvency resolution process had commenced, homebuyers had not participated in it. Accordingly, the court ordered for the resolution process to be started afresh, thus ensuring that the homebuyers would also be able to exercise their newly recognised right to vote in the CoC. ${ }^{71}$ However, the decision to include homebuyers and restart the time period allotted to complete the resolution process was made using Article 142 of the Constitution which allows the court to render complete justice. ${ }^{72}$ The other consideration which influenced the court's decision was the statutory mandate contained in Section 29A of the IBC.

\footnotetext{
${ }^{66}$ Insolvency and Bankruptcy Board of India (Liquidation Process) Regulations, 2016, IBBI/201617/GN/REG005, reg. 37, https://ibbi.gov.in//uploads/legalframwork/b37ac2f0201e2e3c41cfa3d989f58f4d.pdf.

${ }^{67}$ Id. reg. 2B

${ }^{68}$ Chitra Sharma v. Union of India (2018) 18 SCC 575.

${ }^{69} \mathrm{Id}$. ๆศ 36-37.

${ }^{70} I d .9 \uparrow$ 47.1-47.2.

${ }^{71} I d$.

${ }^{72} I d$.
} 
The Court referred to section 29A of the IBC and explained that it prohibits the promoters of corporate debtors from submitting insolvency resolution plans. ${ }^{73}$ Thus, in Chitra Sharma the Supreme Court refused to allow restructuring through a scheme of arrangement that was agreeable to all of its creditors (except homebuyers) even if it meant that the corporate debtor could continue its projects. ${ }^{74}$ The court's analysis on why the MRA could not be implemented because of the prohibition under Section 29A is independent of its concern for homebuyers. This precedent will thus apply to any agreement which is entered into between promoters and the creditors of a corporate debtor in the context of an insolvency resolution plan. The IBC's (and the Supreme Court's) position on an incumbent management's participation in the process of restructuring is unequivocal.

Interestingly, the current Indian approach to connected party sales may be justified based on the UK's experiences with them. Most pre-packs sales in the UK are in the form of sales to connected parties or persons who are directors, shadow directors or associates of the company ${ }^{75}$ In the UK, this practice (also known as phoenixing $)^{76}$ has been criticised especially in the context of pre-packs. Phoenix transactions allow connected parties to use information to which only they are privy in order to negotiate a better deal for themselves. ${ }^{77}$ For instance, it would be in the interest of purchasing directors or parties connected to them who are purchasers that the firm is sold at a lower consideration. ${ }^{78}$ This would reduce the amount of money available for distribution to secured creditors. ${ }^{79}$ A corollary to this criticism is that promoters are allowed to 'shed their debt' and carry on with a their new business irrespective of whether or not they have engaged in any actual course correction. ${ }^{80}$

\section{Justifications for connected party sales}

Sales to connected parties invite more scrutiny in the context of pre-packs because the speed and secrecy of the process do not allow creditors to fully evaluate the plan. ${ }^{81}$ Further, pre-packs

\footnotetext{
73 IBC § 29-A; Chitra Sharma, supra note 68, ๆ甲 36-38.

${ }^{74}$ Chitra Sharma, supra note 68, ๆ $96-38$.

${ }^{75}$ Graham Report, supra note 9, at 38.

${ }^{76}$ Wellard \& Walton, supra note 20, at 170.

${ }^{77}$ XIE, supra note 7, at 94; Wellard \& Walton, supra note 20, at 154; Eugenio Vaccari, English pre-packaged corporate rescue procedures: is there a case for propping industry self-regulation and industry-led measures such as the pre-pack pool?, 31 INT'L COMPANY \& COM. L.R. 170, 181 (2020).

${ }^{78}$ Bo XIE, supra note 7, at 94; FinCH \& MiLmAN, supra note 2, at 405.

${ }^{79}$ FinCH \& MiLman, supra note 2, at 379.

${ }^{80}$ Bo XIE, supra note 7, at 94.

${ }^{81}$ Sandra Frisby, Insolvency Law \& Insolvency Practice: Principles and Pragmatism Diverge? 64 CURRENT LEGAL PROBS. 349, 379 (2011), Walton, supra note 9, at 87.
} 
are normally executed without the creditors' vote of approval. Creditors thus do not have a means to check decisions of the management that have been taken in their own self-interest when the sale is executed through a pre-pack. The Graham Committee Report (2014) commissioned by the Secretary of State for Business ${ }^{82}$ found that pre-pack sales to related parties had thrice the odds of failing compared to sales to unconnected parties. Despite this, the Report did not recommend banning pre-packs ${ }^{83}$ and the UK Government seems to agree with this position for now. The UK Insolvency Act gives the Secretary of State the power to frame regulations for the sale of a company's assets to connected parties. ${ }^{84}$ This includes the ability to require the administrator to get the court's or creditors' approval before affecting such a sale and extends to prohibiting these sales all together. Originally, this power to regulate was to be used before May 2020, and for this reason, has been referred to as a 'sunset' provision. In June 2020, the UK Government amended Insolvency Act ${ }^{85}$ to extend the sunset period to June 2021.

The unique benefits of pre-pack sales to connected parties as identified by the Graham Report are similar to those in the BLRC Report. The Graham report noted that when a corporation is experiencing financial difficulties due to an industrial slow down, it is unlikely that other companies in the industry will be willing to purchase the whole business of the corporate debtor. In such cases, the incumbent management is often the only one willing to purchase the business of the company. In these situations, sales to connected parties are often the only option in order to preserve the business of the company. ${ }^{86}$ More generally, there may be some business failures which cannot be attributed to the management of the company, thus not all insolvency applications are a result of bad management practices. In such circumstances, it would be quite harsh to deprive promoters and directors of a second chance at running their company. ${ }^{87}$

\section{Revaluating section 29A}

It is difficult to imagine a pre-pack negotiation which can be carried out without the corporation of the incumbent management. ${ }^{88}$ Even if the resultant sale is not a related party,

\footnotetext{
${ }^{82}$ Graham Report, supra note 9, at 3.

83 Id. at 54.

${ }^{84}$ Insolvency Act 1986, c. 45, sch. B1, II 60A.

${ }^{85}$ Corporate Insolvency and Governance Act 2020, c. 12, $\S 8$.

${ }^{86}$ XIE, supra note 7, at 94; Graham Report, supra note 9, ๆ 7.51.

${ }^{87}$ XIE, supra note 7, Singh, supra note 46, at 10.

${ }^{88}$ Singh, supra note 46, at 11.
} 
the directors are promoters of a company will have to be involved in the negotiation process as representatives of the corporate debtor. Under the normal insolvency procedure of the IBC, the insolvency professional replaces the company's directors and liaises with the CoC during the resolution process. Since pre-pack negotiations are carried out before the insolvency application is field, there is no insolvency professional to replace the office holders of the company. Once a resolution professional is appointed, it becomes difficult to maintain the secrecy of the insolvency resolution process. It has been suggested that a resolution professional can be voluntarily appointed in the pre-pack process to ensure that all dealings happen at a fair price. ${ }^{89}$ While this may resolve the issue of fairness in connected party sales, it still doesn't ensure that the incumbent management does not influence the resolution professional or that they do not participate in it. A similar suggestion was also made in the $\mathrm{UK} ;{ }^{90}$ it was suggested pre-pack negotiations must only be between insolvency professionals. However, this proved to be impracticable as it is difficult to define when exactly negotiations become pre-pack-negotiations. ${ }^{91}$ If pre-pack negotiations are restricted to insolvency professionals, they will be unnecessarily constricted. ${ }^{92}$

Chitra Sharma has shown that even in India, secured creditors are willing to the negotiate with the incumbent management to reorganise the business. The fact that an amendment had to be passed to prevent secured creditors from selling their securities to the incumbent management shows that connected party sales were willingly adopted by the corporate debtor's management and its secured creditors. A pre-pack regime retaining these restrictions would limit the incentives of the secured creditors and the incumbent management from cooperating during pre-pack negotiations. Creditors who believe that pre-pack negotiations will not allow them to negotiate a deal with the parties they choose (such as promoters and directors) may prefer to simply trigger the insolvency process and take the normal route to insolvency proceedings. At the very least, these restrictions reduce the possible resolution plans that can be implemented through pre-pack negotiations. While the pre-pack sales to connected parties is likely to affect some pre-pack negotiations in India, scepticism about any connected party participation in the insolvency process will unnecessarily complicate all pre-pack negotiations. Accordingly, the IBC needs to (cautiously) embrace the participation of the incumbent management and

\footnotetext{
${ }^{89} I d$. at $15 .$.

${ }^{90}$ Vanessa Finch, Pre-Packed Administrations and the Construction of Propriety, 11 J. OF CORP. L. STUD., 1, 21 (2011).

${ }^{91} I d$.

${ }^{92} \mathrm{Id}$.
} 
promoters of a company in the insolvency resolution process in order to reap the full benefits of a pre-pack regime.

\section{Limiting the reach of the IBC's avoidance provisions}

Section 43 of Chapter III of the IBC defines preferential transactions and Section 44 allows for their avoidance. ${ }^{93}$ Preferential transactions are transactions between the corporate debtor to its creditor, surety or guarantor towards the payment of an antecedent debt or any other liability. ${ }^{94}$ In order for a transaction to be considered preferential in nature, it must put the person to whom the transfer was made in a better position than they would have been prior to the transfer in the event of a liquidation..$^{95}$ The definition of a preferential transaction under Section 43 is largely worded similar to the one contained in Section 239 of the UK Insolvency Act, $1986 .{ }^{96}$

Section 43 states that if such a transfer is made to a related party two years prior to the commencement of the resolution process and to any other party one year prior to the commencement of the resolution process, the transfer is deemed to have been preferential. ${ }^{97}$

Section 45 defines undervalued transactions as those in which a transfer is made as a gift or at a consideration which is significantly lesser than the value of the thing that is being transferred. The wording of the definition of an undervalued transaction under the IBC is also similar to that of the UK's. ${ }^{98}$ However, an undervalued transaction in the UK cannot be avoided if it is made in good faith, no such exception is provided under the IBC..$^{99}$

In Anuj Jain v. Axis Bank ${ }^{100}$ it was held that Chapter III (which deals with liquidation) would also be applicable to Chapter II which contains the insolvency resolution process. Even if a company is not likely to go into liquidation (either because a plan was not approved or because the creditors decided to liquidate), Anuj Jain would allow a transaction to be avoided by a resolution professional after the resolution process has commenced. The bare text of the IBC states that a resolution professional or liquidator can ask for an order under the IBC's avoidance

\footnotetext{
${ }^{93}$ IBC, supra note $23, \S 43-44$.

${ }^{94}$ Id. $§ 43$.

${ }^{95}$ Id. $\S 43(2)(\mathrm{b})$

${ }^{96}$ Insolvency Act 1986, c. 45, § 239.

${ }^{97}$ IBC, supra note 23, § 43(2); Anuj Jain v. Axis Bank (2020) SCC Online SC 237.

${ }^{98}$ Insolvency Act 1986, c. 45, § 238(4).

${ }^{99} \mathrm{Id}$.

100 Anuj Jain, supra note 97.
} 
provisions. ${ }^{101}$ From the bare text, it is unclear whether a resolution professional's power to ask for these orders are referred to in the context of a $\mathrm{CoC}$ approved liquidations or whether they can be used immediately after the resolution process begins. Anuj Jain has given a clear mandate that sections 43 and 45 in Chapter III of the IBC apply to Chapter II resolution processes. ${ }^{102}$ Thus, a resolution professional will be allowed to avoid transactions even if the company is not heading towards liquidation.

In the UK, for example, avoidance provisions do not come in the way of pre-packs because the actual transaction takes place during the formal insolvency proceedings prior to which, there are only negotiated arrangements in place. ${ }^{103}$ Thus, a pre-pack cannot be challenged for being a preferential transaction or an undervalued one. ${ }^{104}$ Under the IBC, the word 'transaction' has a broad an inclusive definition and extends to any agreement or arrangement in writing for the transfer of assets, funds, goods, or services from the corporate debtor. ${ }^{105}$ The definitions under sections 43 and 45 use the word 'transfer' and not 'transaction'. Transfers are defined inclusively but their meaning is not as broad as that of a transaction. A transfer refers to any transfer of a right including sales, mortgages, gifts etc. ${ }^{106}$ Unfortunately, this does not provide much clarity as the section headings of the IBC's avoidance provisions refer to 'preferential transactions' and 'undervalued transactions'; these phrases have been used elsewhere in the IBC as well. ${ }^{107}$ There is thus the possibility that these sections can be used to set aside any prepack negotiation prior to the insolvency application as preferential or undervalued based on the existence of negotiated agreements. This problem is compounded by the fact that these sections operate without any regard for the intention behind these transactions. ${ }^{108}$ There is thus a strong case for the application of sections 43 and 45 to pre-pack negotiations, even if the arrangements were reached to ensure that the successful preservation of the debtor's assets. Before deciding on the more substantial features of India's pre-pack regime, law makers will have to ensure that interpretations of section 29A and sections 43 and 45 do not jeopardise the stability of pre-packaging. The next section will discuss the options available to India for the

\footnotetext{
${ }^{101}$ IBC, supra note $23, \S \S 44,47$

102 Anuj Jain, supra note 97, 9 甲 72-77

103 XIE, surpa note 7 , at $124-125$.

${ }^{104} \mathrm{Id}$.

105 IBC, supra note $23, \S 3(33)$.

${ }^{106}$ Id. $\S 3(34)$.

${ }^{107}$ Id. $\S \S 29 A, 43,44,45,47$.

${ }^{108}$ Anuj Jain, supra note 97, \[82
} 
introduction and regulation of pre-packs by drawing from the experiences of the UK and the US.

\section{IMPLEMENTATION OF PRE-PACKAGING IN THE UK AND THE US}

\section{A. Choosing a route to pre-packaging}

Pre-packaging has neither been explicitly mentioned in the insolvency regime of the UK nor the US. Yet both these regimes have seen pre-packaging become an important and prevalent method of affecting business sales of distressed corporations. In the UK, there are no statutory regulations which specifically refer to pre-packs, pre-packs here evolved through the use of the administrator's power to sell a company's assets without creditors' approval. A similar type of pre-pack emerged through the creative and unprecedented use of section 363 of the US Bankruptcy Code. Chapter 11 of the US Bankruptcy Code takes a different approach. Without defining pre-packs, Chapter 11 provides a route to pre-packing. The introduction of Chapter 11 pre-packs in the US was thus legislatively sanctioned and controlled. The regulatory implications (or more accurately, challenges) of pre-packs that emerge from existing legislation and pre-packs that are deliberately introduced are very different and will be the subject of the following discussion. Given the diverse practices that can constitute a pre-pack, it is important that India chooses the most optimal route for their introduction. A comparison between the US and the UK will make for apt guidance on this issue as both of these regimes contain different routes to the introduction of pre-packs.

\section{Evolution of pre-packs in the UK}

The UK insolvency regime is contained in the Insolvency Act, 1986. ${ }^{109}$ The Act provides for three routes to formal rescue which include, company voluntary agreements (CVAs), administrative receivership, and administration. ${ }^{110}$ Administration receivership is declining in its use after the Enterprise Act, 2002, ${ }^{111}$ which only allowed creditors to appoint administrative receivers if they hold a charge that was created prior to September 2003. ${ }^{112}$ Administrative receivership has thus largely been replaced with administration. This was a manifestation of

\footnotetext{
${ }^{109}$ Insolvency Act 1986, c. 45.

${ }^{110} \mathrm{Id}$. parts I-III.

${ }^{111}$ Enterprise Act 2002, c. 40, § 250; FINCH, supra note 3, at 327-28.

112 FinCH, supra note 3, at 359.
} 
the rescue oriented nature of the Enterprise Act, 2002. ${ }^{113}$ The UK has seen a rise of pre-pack sales after the Enterprise Act and its introduction of a more streamlined administration procedure including out-of-court appointment of administrators. ${ }^{114}$ A study published in 2007 found that 35 per cent of business sales were through pre-packs; ${ }^{115}$ the same study also suggests that the actual percentage may be higher, somewhere between $50-80$ percent. ${ }^{116}$

The UK began its paradigm shift from a collection and distribution oriented insolvency regime to a rescue oriented one after the publication of the Cork Report. ${ }^{117}$ The Committee inquired into the insolvency laws which were in the UK and recommended changes. On the basis of these recommendations, the UK Insolvency Act 1986 (currently in force) was drafted. Prepacks were a result of the shift towards a rescue culture in the UK. ${ }^{118}$ More specifically, prepacks emerged from the desire to stabilise CVAs in the context of insolvency. ${ }^{119}$ The problem posed by the regular CVA method was that a single creditor could ruin these efforts by filing a winding up petition. ${ }^{120}$ The pre-pack essentially combines the formality and the protections of insolvency (such as the moratorium) with the flexibility of the CVA in the UK. ${ }^{121}$

\section{Pre-packs as sales during administration}

In a typical administration, the administrator will have to present proposals for the reorganisation of the company within eight weeks of the commencement of administration proceedings. These proposals are voted upon and approved by the company's creditors through a simple majority. ${ }^{122}$ All of these procedures happen under the protection of a moratorium on recovering securities and starting or maintaining legal proceedings against the debtor. ${ }^{123}$ Anyone who wishes to pursue a remedy against a company undergoing administration will need the permission of the administrator or the court. ${ }^{124}$ Schedule B1 prevents an

\footnotetext{
113 Id. at 254-55.

${ }^{114}$ In Re: Transbus Ltd., supra note 42; FINCH, supra note 3, at 458; Frisby, supra note 20, at 15-16.

${ }^{115}$ Frisby, supra note 20, at 15-16

${ }^{116} I d$.

${ }^{117}$ Report of the Review Committee on Insolvency Law and Practice, 1982, Cm. 8558 (UK); XIE, supra note 7 , at 35 .

${ }^{118}$ XIE, supra note 7 , at 35.

${ }^{119} \mathrm{Id}$. at 40.

${ }^{120}$ Id.; FINCH \& Milman, supra note 2, at 366-367.

${ }^{121}$ Firsby, supra note 20, at 18-19.

${ }^{122}$ Insolvency Act 1986, c. 45, sch. B1, ๆ 3.

123 Id. $\ 42$.

${ }^{124} \mathrm{Id}$.
} 
administrator's proposal from affecting the rights of a secured creditor to enforce their security. ${ }^{125}$ Accordingly, it is mostly the unsecured creditors who vote on the proposals to the extent of their debt. ${ }^{126}$ Secured creditors will also vote on the proposals, but only to the extent that their debt is not covered by their security. ${ }^{127}$ A proposal is approved once a majority of creditors vote in its favour. Pre-pack sales have been made possible in the UK through the powers granted to the administrator. Schedule B1 also allows the administrator to exercise powers granted to them under Schedule 1 of the Insolvency Act. One of the powers conferred by Schedule 1 is the ability to sell the debtor's property either through auction or private sale. This power can be exercised without the authorisation of creditors or the court's approval. ${ }^{128}$ Pre-pack sales in administration have evolved through this route.

Unlike the process in a regular administration, most of the negotiations and decision making in a pre-pack happens in the pre-formal stage (before the administrator is officially appointed). ${ }^{129}$ In a regular administration, the management has to function under the supervision of the administrator and cannot do anything which would conflict with the functions of the administrator. In a pre-pack, the management of the distressed company is actively involved in finding new sources of funds, negotiating with existing creditors, and marketing a plan to potential buyers for the purchase of the company's business. ${ }^{130}$ Pre-packs allow the management of the company more control over its insolvency process. This change in the framework of decision making has significant implications for the management's incentives to choose which method of administration they want to pursue. Unsurprisingly, the incumbent management is more incentivised to enter into pre-pack negotiations than they are to simply file a formal administration application without a pre-pack in place. ${ }^{131}$

During the pre-formal stage, the promoters, directors, shareholders, and creditors of the distressed company can hire insolvency professionals to help rescue the company. These insolvency professionals need not be insolvency practitioners who can fulfil the statutory role of the administrator. ${ }^{132}$ However, they are empowered to negotiate resolution plans that would

\footnotetext{
${ }^{125}$ Id. $₫ 73$.

${ }^{126}$ XIE, supra note 7, at 62.

${ }^{127} \mathrm{Id}$.

${ }^{128}$ In Re: Transbus Ltd., supra note 42; In Re: Hellas Telecommunications [2009] EWHC 3199 (Ch.)

${ }^{129}$ FINCH \& Milman, supra note 2, at 371, 397; XIE, supra note 7, at 35, 73; Walton, supra note 9, at 86;

${ }^{130}$ XIE, supra note 7, at 93-94

${ }^{131}$ Id. 94.

${ }^{132}$ Id. 75 .
} 
be given effect in a statutory insolvency procedure. Since these professionals are not office holders (unlike administrators), they are free to protect the interests of their client over those of other claimants of the company. ${ }^{133}$

Once a pre-pack is negotiated, there a bias to conform to these negotiations even after an administrator has been appointed and the formal administration process has commenced. ${ }^{134}$ This strong bias towards implementing the terms of a pre-pack exists largely because the resolution professional who helped negotiate the pre-pack is appointed as the administrator. ${ }^{135}$ Further, there is often difficult secure adequate funds in order to maintain a company's relationship with its suppliers and customers by the time administration proceedings have been filed. ${ }^{136}$ Thus, while the administrator could potentially take the insolvency proceedings in a different direction than the pre-pack negotiations, they are more likely to stick with the plan they had helped negotiate. ${ }^{137}$ Pre-packs thus by-pass creditors' voting rights and often keep them in the dark until after the sale is completed. ${ }^{138}$ General creditors tend not to get a good deal as the company's assets are usually undervalued when sold. However, they are not empowered to do anything about this. Suing a company which has just declared bankruptcy is not a viable option, it is also difficult to prove malpractice against directors and insolvency professionals. $^{139}$

\section{Pre-pack routes in the US}

Chapter 11 of the US Bankruptcy Code contains the law governing corporate reorganisations and includes a route to pre-packaging. Chapter 11 lays down rules for negotiating a plan and soliciting votes from creditors before a bankruptcy petition is filed. The Chapter 11 pre-pack route thus largely retains the informational and participation rights of creditors that would be granted to them in a regular insolvency proceeding. The key difference between a regular Chapter 11 reorganisation and a Chapter 11 pre-pack is that in the latter, creditors' votes are solicited before a bankruptcy petition is filed. Another route to pre-packing under the US

\footnotetext{
${ }^{133} I d$.

${ }^{134}$ Id. 78; FINCH \& MiLmAN, supra note 2, at 397.

${ }^{135}$ XIE, supra note 7, at 78; Wellard \& Walton, supra note 20, at 147.

${ }^{136}$ XIE, supra note 7, at 78; Ellina, supra note 8, at 189-90.

${ }^{137}$ Wellard \& Walton, supra note 20, at 147.

${ }^{138}$ Id.; XIE, surpa note 7, at 84; Finch, supra note 90, at 7-8.

${ }^{139}$ FinCH \& Milman, supra note 2, at 379.
} 
Bankruptcy Code is section 363, through which the assets of a company undergoing Chapter 11 reorganisation proceedings can be sold without creditor approval but subject to a bankruptcy court's approval. A company involved in Chapter 11 proceedings can thus proceed to execute a pre-pack sale under section 363 of its entire business. For the sake of convenience, this paper will refer to the statutory route to pre-packs under Chapter 11 as "Chapter 11 pre-packs" in order to differentiate them from section 363 sales.

\section{Section 363 sales in the US}

The loose counterpart of administration sales in the UK is the section 363 sale under the US Bankruptcy Code. Section 363 allows a US a bankruptcy trustee (roughly equivalent to an administrator) to sell, lease or otherwise dispose of the property of a corporate debtor once they enter into Chapter 11 reorganisation proceedings. The use of section 363 as a means to implement pre-pack negotiations was not foreseen by the US Bankruptcy Code and was a result of business creativity. The key difference between the UK and the US law for selling a debtor's property during insolvency proceedings is that the US law requires the debtor or trustee to give a notice and conduct a hearing before effecting such a sale. ${ }^{140}$ If such a sale is not consented to by every person having an interest in the property being sold (such as creditors), then the sale will need to be approved by a bankruptcy court. ${ }^{141}$ This is why debtors and bankruptcy trustees need to apply to the bankruptcy court before disposing off assets under section $363 .{ }^{142}$ The bankruptcy court which will hear the objections of creditors before approving a section 363 sale. ${ }^{143}$ The bankruptcy court hearing is not a substitute for the creditors' voting process under a typical Chapter 11 reorganisation. During these hearings, bankruptcy courts are not concerned with whether a majority of creditors would have voted for the proposed section 363 sale, there is a different standard for assessing section 363 sales. The US Bankruptcy Code does not provide any standards or guidelines that steer judicial evaluations of section 363 sales. Accordingly, courts have developed their own standards to adjudicate applications under Section 363. This is permissible given the wide powers given to Bankruptcy Courts under Title

\footnotetext{
14011 U.S.C. $\$ 363(\mathrm{f})$.

${ }^{141}$ Nocilla, supra note 48, at 72. See What is a 363 Sale?, CORPORATE FinANCIAL Institute, https://corporatefinanceinstitute.com/resources/knowledge/deals/363-sale/.

${ }_{142}$ See Nocilla, supra note 48 , at 72 (discussing why seeking court approval is not always a strict requirement but has become common practice for the benefit of the purchaser).

143 Jason Grege, An Efficiency Model of Section 363(b) sales, 92 VA. L. REV. 1639, 1643; XIE, supra note 7, at 205; Nocilla, supra note 48, at 72.
} 
11. ${ }^{144}$ Section 105(a) of the US Bankruptcy Code empowers bankruptcy courts to pass orders which they consider necessary to give effect to the provisions of the Code. ${ }^{145}$

\section{Chapter 11 pre-packs}

To commence involuntary bankruptcy proceedings, three or more unsecured creditors having dues exceeding 10,000 USD file a bankruptcy application against the corporate debtor. ${ }^{146}$ Thereafter, the corporate debtor has 120 days to submit an insolvency resolution plan. ${ }^{147}$ Within these 120 days, the corporate debtor has the exclusive right to formulate a plan for the consideration of all creditors. ${ }^{148}$ If this plan is rejected, then other claimants can propose plans which are then considered and voted upon. The corporate debtor can also file a bankruptcy petition, this is typically known as voluntary bankruptcy. ${ }^{149}$ Voluntary bankruptcies are usually accompanied with a reorganisation plan, which is approved by claimants and confirmed by the bankruptcy court in the same manner as a plan proposed during involuntary bankruptcy proceedings. ${ }^{150}$

Chapter 11 plans need to divide claimants into classes with other similarly placed claimants and provide them with a disclosure statement before they vote on the plan. ${ }^{151}$ The disclosure statement needs to contain all information that would be material to a claimant's decision to vote on a plan. ${ }^{152}$ A class of claimants approves a plan if they vote on it by a two-third majority of the total debt owed to the class so that this vote represents at least half the claimants in the relevant class. ${ }^{153}$ Claimants whose debts are being paid in full are deemed to have accepted the plan and claimants who receive nothing under the plan are deemed to reject it. So the votes which really need to be won by a plan are those of 'impaired claimants' or claimants who's

\footnotetext{
14411 U.S.C. $§ 105$ (a). See XIE, supra note 7, at 209.

14511 U.S.C. $\$ 105(\mathrm{a})$.

14611 U.S.C $\S 303(b)$.

147 11. U.S.C. § 1121. See, Xie, supra note 7, at 179; Chapter 11 - Bankruptcy Basic: Who Can File a Plan, US COURTS https://www.uscourts.gov/services-forms/bankruptcy/bankruptcy-basics/chapter-11-bankruptcy-basics.

148 Chapter 11 - Bankruptcy Basic: Who Can File a Plan, US COURTs https://www.uscourts.gov/servicesforms/bankruptcy/bankruptcy-basics/chapter-11-bankruptcy-basics.

149 11 U.S.C. $\$ 301$; XIE, supra note 7, at 177-178.

150 Chapter 11 - Bankruptcy Basic: Who Can File a Plan, US COURTS https://www.uscourts.gov/servicesforms/bankruptcy/bankruptcy-basics/chapter-11-bankruptcy-basics.

15111 U.S.C. $\$ \S 1122,1126$.

15211 U.S.C. $§ 1126($ b). See Mark D. Plevin et al., Pre-Packaged Asbestos Bankruptcies: A Flawed Solution, 44 S. TEX. L. REV. 883, 886 (2003).

15311 U.S.C $\S 1126$.
} 
debts are not being fully paid. ${ }^{154}$ A bankruptcy court will confirm a plan if it meets the requirements set out in section 1129 of Chapter 11, one of these requirements is the unanimous approval of the plan by all classes. ${ }^{155}$ However, in case such unanimous acceptance is not received by a plan, the bankruptcy court can still approve a plan through the cramdown provisions under the Chapter 11. Cramdown provisions require that at least one impaired class of creditors approves the plan and that the plan treats all claimants in a fair and equitable manner. ${ }^{156}$ In the ordinary course of Chapter 11 proceedings, the plan is voted on and accepted after the commencement of the bankruptcy proceedings.

Chapter 11 also allows the corporate debtor to not only formulate but also seek the approval of a plan prior to the filing of a bankruptcy petition. ${ }^{157}$ This is the other route to pre-packaged insolvency in the US. In Chapter 11 pre-packaging, a plan and disclosure statement are filed before the bankruptcy court. The court will conduct a single hearing to determine the adequacy of the disclosures and whether the plan meets the conditions under section $1129 .{ }^{158}$ Even in pre-packaged Chapter 11 reorganisation plans, claimants need to be divided into classes where all members of each class are substantially similar to each other and the plan needs to be approved by the requisite majorities under Chapter $11 .{ }^{159}$ The bankruptcy court retains the authority to scrutinise the classes of claimants and decide whether their demarcation (and consequently the vote of acceptance) is valid. ${ }^{160}$ Once a pre-packaged reorganisation plan is confirmed by the bankruptcy court, it will bind all claimants notwithstanding whether or not they individually voted in favour of it. The debtor's obligations to creditors prior to the plan will be replaced with those enumerated in the plan. ${ }^{161}$ Chapter 11 pre-packs are typically faster than conventional Chapter 11 reorganisations which often take years to complete. Chapter 11 pre-packs can be confirmed within 30-45 days from the date of formal filing with the bankruptcy court. ${ }^{162}$

\footnotetext{
154 Id. XIE, supra note 7, at 182.

15511 U.S.C. $\$ 1129(7)-(8)$.

${ }^{156}$ XIE, supra note 7, at 183-184; Brian P. Hanley, Preserving Creditors Bargain in Chapter 11 Cramdowns, 8 BrooK. J. OF CORP., COM. \& FIN. L. 494, 500 (2014).

15711 U.S.C. $\S 1126(b)$.

158 Plevin et al, supra note 152 , at 888 .

159 11. U.S.C. $\$ 1126$ (b); See, XIE, supra note 7, at 189-90.

160 Bruce A. Markell, Clueless on Classification: Toward Removing Artificial Limits in Chapter 11 Claim Classification, ARTICLES BY MAURER FACULTY, 1, 3 (1995).

${ }^{161} I d$.

162 Plevin et al, supra note 152 , at 888.
} 
The Chapter 11 sanctioned pre-pack is relatively straightforward and offers more protections to creditors than pre-packs in the UK. ${ }^{163}$ This is chiefly done by requiring disclosures prior the plan's execution and preserving creditors' voting rights. These protective measures, however, do reduce the speed associated with Chapter 11 pre-packs when compared to other prepacks. ${ }^{164}$ This route to pre-packing in the US lends flexibility to negotiations and allows them to be carried out discreetly, the need to obtain creditors' approval increases the time required to complete the pre-pack. ${ }^{165}$ However, the regulation of Chapter 11 pre-packs is more robust and leads to fairer outcomes. Pre-packs under Section 363 and Schedule B1 have been difficult to regulate as new devices to ensure their fairness need to be imposed on an existing legislative paradigm which did not initially require them. Some initiatives to regulate pre-packs and increase the fairness of their outcomes have been discussed below.

\section{B. Regulating pre-packs: assessing the adequacy of current reformative trends}

The UK and the US have both contemplated ways to make the pre-pack process a fairer one. In the UK the focus has been on self-regulation and increasing transparency. The US has not implemented any pre-pack specific reforms related to transparency for section 363 sales. However, there has been a push to reduce the speed with which such sales are effected after Chapter 11 proceedings commence. Chapter 11 pre-packs are regulated by the US Bankruptcy Code itself and need to comply with most of the requirements applicable to regular reorganisations. This section discusses the current trends in pre-pack reforms and critically appraises their effectiveness.

\section{Transparency and self-regulation driven reforms of the UK}

In order to increase the transparency associated with the pre-pack process, the Joint Insolvency Committee of the UK introduced the Statement of Insolvency Practice - 16 of pre-packaged sales in administration (SIP-16). ${ }^{166}$ SIP- 16 has been updated thrice since its introduction in

\footnotetext{
163 XIE, supra note 7, at 200.

${ }^{164} I d$. at 194.

${ }^{165}$ Kim Korress, Bankrupting Bankruptcy: Circumventing Chapter 11 Protections Through Manipulation of the Business Justification Standard in \$363 Asset Sales, and a Refined Standard to Safeguard Against Abuse, 63 FLA. L. REV. 960, 960-61 (2011).

${ }^{166}$ Report of the First Six Month' Operation of the Statement of Insolvency Practice 16, InSOLVENCY SERVICE, ๆ 2.6, Jun. 2009),
} 
2009, the latest version having been issued in $2015 .{ }^{167}$ has detailed transparency requirements; it requires resolution professionals to provide creditors with a brief history of the distressed company and a justification for why a pre-packaged sale was undertaken. ${ }^{168}$ Specifically, the administrator must explain why it was not appropriate to offer the business for sale through the regular administration procedure. ${ }^{169}$ Moreover, the administrator is required not only to mention the marketing strategies undertaken but also justify them to creditors through the SIP16 statement. $^{170}$

If an asset valuation is conducted, then this valuation along with the actual consideration paid in the sale must also be included under SIP - $16 .{ }^{171}$ The identity of the purchaser should also be disclosed, especially if they are a connected party. Importantly, administrators have to disclose the details of their appointment and the extent of their involvement in the pre-pack stage. ${ }^{172}$ These disclosures help creditors decide whether they are satisfied with an administrator's conduct in a pre-packed sale and whether they want to take any action against them for a breach of duty. ${ }^{173}$ The limitation of SIP-16 is that it can be disclosed to creditors up to seven days after the transaction is completed. It is thus difficult for affected creditors to actually act on the disclosures since the approved. ${ }^{174}$

Transparency requirements are expected to work through forces in the market for resolution professionals. The expectation is that administrators who adhere to transparency requirements and are able to justify pre-packs properly will be preferred over others who do not comply with these requirements. But this market for insolvency resolution professionals is also heavily influenced by the incumbent management and secured creditors (mostly) who play a role in appointing administrators and paying for pre-packs. There will thus always be a market for resolution professionals who can secure work in cooperation with the incumbent management

\footnotetext{
https://assets.publishing.service.gov.uk/government/uploads/system/uploads/attachment_data/file/301183/sip16first_six_months 2009.pdf.

${ }^{167}$ Statement of Insolvency Practice 16 (Version 3), 2015, https://www.icaew.com/Imedia/corporate/files/technical/insolvency/regulations-and-standards/sips/england/sip-16-e-and-w-prepackaged-sales-in-administrations-2015.ashx

168 Id. 3

169 Id.

$170 \mathrm{Id}$.

171 Id. 5-6

${ }^{172}$ Id. 5

${ }^{173}$ Finch, supra note 90, at 28; FinCH \& MiLman, supra note 2, at 379 (discussing how it is difficult for general creditors to sue companies which have empty pockets after the pre-packaged asset sale is complete).

${ }^{174}$ Anthony Wijaya, Pre-Pack Administration Sale: A Case of Sub-Rosa Debt Structuring, 25 InT'L InSOLVENCY REV. 119, 123-124 (2016); Wellard \& Walton supra note 20, at 146.
} 
and focus on the pre-pack negotiations rather than the comprehensiveness of their SIP-16 statements. expected to work through the market by creating demand for administrators and resolution.

Another more recent effort to increase the integrity of pre-packs, especially pre-packs to connected parties is the pre-pack pool recommended by the Graham Review Report. The prepack pol comprises independent experts who review the proposed sale to a connected party and give their opinion on it. This is a purely voluntary process, and has not been widely used in the UK. The UK's efforts towards regulating pre-packs have been largely circumspect and inadequate because of their voluntary nature and post-facto nature. The limitations of a voluntary, transparency-oriented regulation regime have prompted writers in the UK to suggest stronger forms of regulation. For instance, it has been suggested that the pre-pack pool's approval needs to be made mandatory in order for it to actually work. However, these suggestions have been met with opposition as they will inevitably reduce the speed of secrecy associated with a pre-pack (depending on which suggestion is implemented). The experience of the UK shows the complications involved in regulating pre-packs, especially once they have already come into use.

\section{Pre-pack disclosures and regulation in the US}

Chapter 11 pre-packs need to meet the same disclosure requirements as regular pre-packs. ${ }^{175}$ This means that they must provide creditors with 'adequate information' to ensure that their vote is informed. The standard for determining for what comprises adequate information is that would be enough for a 'hypothetical reasonable investor' from a class to make a decision on a plan. ${ }^{176}$ Chapter 11 accommodates the need to varied disclosure requirements depending on the accessibility of information about a company and its history. It is for bankruptcy judges to make the final decision about whether the disclosure give was adequate. In the context of Chapter 11 pre-packs, bankruptcy courts can order for votes to be re-solicited if it is found that the disclosure given is inadequate. This is a strong incentive for the debtor to ensure that adequate information is provided to creditors before their votes are solicited. There is thus

\footnotetext{
17511 U.S.C. $\S \S 1125(a), 1126(b)(2)$. See, Pelvin et al., supra note 152, at 888.

${ }^{176}$ Glen W. Merrick, The Chapter 11 Disclosure Statement in a Strategic Environment, 44 BuS. LAW. 103, 10910 (1988); Nicholas S. Gatto, Disclosure in Chapter 11 Reorganizations: The Pursuit of Consistency and Clarity, 70 CORNELl L. REV. 733, 738-39 (1985).
} 
statutory guidance for disclosure requirements of Chapter 11 pre-packs. The more contentious issue in the US has been the regulation of section 363 pre-packs.

The Report of the American Bankruptcy Institute Commission, 2014 (ABI Report) made recommendations to increase the stakeholder protections under a section 363 sale. In the status quo, secured creditors have a lot of control over control over section 363 sales by virtue of their control over the debtor. ${ }^{177}$ Unsurprisingly, section 363 sales usually prioritise the interests of secured creditors as they are privy to the negotiations which result in the final sale. The ABI Report made two important recommendations were made to promote transparency and unsecured stakeholders' participation and protection. The first recommendation was a 60-day moratorium on section 363 sales. The ABI Report noted that After 2000, speed with which section 363 sales are being approved as significantly increased. ${ }^{178}$ This reduced the extent of marketing involved in the sale and reduced the time available to creditors and stakeholders to prepare and file their objections before the bankruptcy court during the hearing. ${ }^{179}$ Accordingly, the report recommended that a 60-day moratorium on section 363 sales be imposed after a Chapter 11 petition is filed. ${ }^{180}$ This would mean that a sale cannot be proposed immediately after Chapter 11 proceedings are filed and that the 60 days would have to elapse. The ABI Report recognised that there would be some cases which require expedited sales and the 60-day moratorium may be detrimental to the value of the company's assets in such a case. ${ }^{181}$ However, the exceptional cases should not inform the basis of general rule making for section 363 sales. $^{182}$

The second recommendation directly addressed the reduced protections given to stakeholders under section 363 sales compared to Chapter 11 plans. The ABI Report recommended that standards should be legislated for the confirmation of section 363 sales just as they exist for Chapter 11 plans under section 1129 of Title 11. In the context of a section 363 sale, these provisions would require that the plan is proposed in good faith, that it is reasonable, and that

\footnotetext{
177 Nocilla, supra note 48 , at 75 .

178 D.J. Baker et. al., Final Report and Recommendations, Commission to Study the Reform of Chapter 11, AMERICAN BANKRUPTCY INSTITUTE, 84, (2014), https://abiworld.app.box.com/s/vvircv5xv83aavl4dp4h

${ }^{179} I d$. at $84-85$.

${ }^{180} I d$. at 87.

${ }^{181} \mathrm{Id}$. at 85

${ }^{182}$ Id. at 86 .
} 
some of the purchase money is reserved for the payment of unsecured creditors per the their statutorily recognised priority. ${ }^{183}$

These ABI recommendations have not been implemented by Congress, they also faced strong opposition from the industry, specifically, the Loan Syndications and Trading Association ${ }^{184}$ (LTSA). ${ }^{185}$ The LTSA acknowledged that 363 sales can operate to the prejudice of unsecured creditors but it maintained that the need for court approval was a sufficient check on any excesses of section 363 sales. ${ }^{186}$ The LTSA also objected to the connection between 363 sales and increased control by secured creditors on the grounds that there was inadequate empirical evidence to suggest this. However, other scholars would disagree with the view and there is ample literature which documents the increased influence of secured creditors in a section 363 sale compared to Chapter 11 reorganisation plan (pre-pack or otherwise). ${ }^{187}$

\section{The limitations of non-statutory regulations}

While the issue with pre-packs ostensibly appears to be one related to voting rights and information asymmetry, this itself paints an inaccurate picture. In the UK, smaller creditors are disenfranchised even in regular administration proceedings. Studies have found that even in regular administrations, unsecured creditors do not vote on plans to sell the company. ${ }^{188}$ Transparency, though an important means to secure fairness and accountability in prepackaging only empowers creditors informationally. It does not ensure that creditors are able to act on this information. More timely disclosures about the pre-pack process will help creditors make decisions about sustaining their relationship with the company (such as suppliers) and prompt them to take legal action, these disclosures seldom alter the position of smaller creditors once a pre-pack is complete. ${ }^{189}$ The informational focus of the SIP-16 does not increase creditor participation and it is participation that can actually give creditors a say in how their interests are being dealt with in a pre-pack. ${ }^{190}$ The voluntary nature of the pre-

\footnotetext{
${ }^{183} I d$. at 201. See 11 U.S.C. $\S 507(3)$.

${ }^{184}$ The LTSA is the principle advocate for the corporate loan market in the US.

${ }^{185}$ LTSA to ABI Commission of Chapter 11 Reform, AMERICAN BANKRUPTCY INSTITUTE, https://www.abi.org/feed-item/1sta-to-abi-commission-on-chapter-11-reform-no-way-jos\%C3\%A9 ${ }^{186} I d$.

${ }^{187}$ Korres, supra note 165, at 967; Nocilla, supra note 48, at 76; Anne Anderson and Yung-Yu Ma, Acquisitions in Bankruptcy: 363 Sales versus Plan Sales and the Existence of Fire Sales, 22 AM. BANKR. INST. L. REV. 1, 17 (2014).

${ }^{188}$ FINCH \& MiLmAN, supra note 2, 379 (see footnote 50 therein).

${ }^{189}$ XIE, supra note 7 , at 76.

${ }^{190}$ Wijaya, supra note 174 , at 132.
} 
pack pool made it vulnerable to the same problems. Without a legislative mandate or some sanction associated with not using the pool, there is little incentive for parties to consult the pre-pack pool for connected party sales.

These deficiencies in the UK's insolvency regime have been linked to the lack of legislative recognition of and regulation of pre-packs. ${ }^{191}$ It has been suggested that the courts need to play a more active role in approving pre-pack sales. ${ }^{192}$ UK courts tend to defer to the decision of and administrator when it comes to the pre-pack sales. The US model of courts approving section 363 sales has been considered as a guide judicial intervention for pre-pack sales in the UK. ${ }^{193}$ However, the treatment of section 363 sales by courts in the US is in itself quite complex. These issues along with an examination of the UK's deferential approach to the prepack sales during administration have been discussed in the next section.

\section{Judicial treatment of pre-packs}

\section{Trends in the UK}

UK courts usually defer to the administrator's decisions when confronted with a challenge to a pre-pack. The deference shown to an administrator's decision to pre-pack by courts in the can be linked to the office of the administrator. Before 2015, companies could 'pre-pack' by entering into voluntary liquidations and appointing a liquidator who is agreeable to the company's plan. This process, like pre-packs allowed the assets of a company to be disposed of without creditors' approval. The UK Government legislated against this practice by amending section 166 of the Insolvency Act in 2015, the amendment required the court to approve the decisions of liquidators. ${ }^{194}$ The key difference between administrators and the liquidators who used to be appointed during voluntary liquidations is that the former are office bearers. This may be one of the reasons why the UK has no legislated any statutory controls of pre-packs while it has effectively prevented the use of voluntary liquidations to pre-pack. ${ }^{195}$ The Courts in the UK thus perform important oversight functions in the context of pre-packs, in the absence of any legislation courts are the only authority that can decide on the validity of a pre-pack sale during administration.

\footnotetext{
${ }^{191}$ Wellard \& Walton, supra note 20, at 146.

192 Wijaya, supra note 174, at 132; Vaccari, supra note 77, at 188

${ }^{193}$ Wijaya, supra note 174, at 133.

${ }^{194}$ Wellard \& Walton, supra note 20, at 153 (see footnote 69 therein).

${ }^{195} I d$.
} 
A challenge to a pre-pack is made in the form a challenge to the administrator's decisions to sell substantially all the assets of a company without creditors' approval. On multiple occasions, UK courts have held that an administrator's Schedule I power to sell a debtor's assets during administration extends to the ability to sell all the debtor's assets. In $T \& D$ Industries Plc, ${ }^{196}$ the question before the court was whether the administrator needed the court's approval to sell the debtor's property under the then applicable Insolvency Act. ${ }^{197}$ The court held that the administrator could exercise their powers before their proposals were approved by the company's creditors. Section 17 of the Insolvency Act (prior to amendments effected through the Enterprise Act) empowered the administrator to manage the business and property of the company in accordance with the court's directions. The court held that the phrase 'in accordance with any directions given by the court' did not mean that the administrator required the court's permission to exercise their powers. Rather, the phrase meant that if any directions were given by the court, the administrator must follow them. Thus, administrators were not precluded from using their powers based on their own initiative. ${ }^{198}$

The judgement recognised that a decision to sell all or substantially all the assets prior to the meeting of creditors would effectively nullify the creditors' right to vote on the administrator's proposal. However, there were some situations which may warrant such expedient action. The court held that the administrator must be conscious of the implications of their decision on creditor's decision-making rights and weigh them appropriately with other factors affecting the case. It was suggested that wherever it was possible, the administrator must at least consult the company's creditors before a decision to sell the assets of the company is made. This case was decided prior to the Enterprise Act 2002 which amended the Insolvency Act and the same issue was again raised with regard to the in Re: Transbus International Limited. ${ }^{199}$ The court remarked that the Enterprise Act reflected a conscious decision of the legislature to reduce the court's involvement in administrations. After perusing the provisions of Schedule B1, the court held that administrators retained the power to dispose of the company's property without the approval of the court or the company's creditors. Courts in the UK have thus authorised

\footnotetext{
${ }^{196}$ In Re: Transbus Ltd., supra note 42.

${ }^{197}$ In Re: Hellas Telecommunications, supra note 128.

${ }^{198}$ In Re: Transbus Ltd., supra note 42.

199 Re: Hellas Telecommunications, supra note 128, 9
} 
administrators to enter into pre-packs, this sanction has even been extended to cases where a major creditor has objected to the pre-pack. ${ }^{200}$

The UK's courts have thus embraced an administrator's power to dispose of a company's assets before a creditor's vote. This power of the administrator has been upheld by UK courts despite multiple challenges. In the absence of being able to challenge the administrator's power to carry out a business sale, creditors have challenged the administrator's appointment itself. This would have an implication on the success of a pre-pack as a newly appointed administrator will not have participated in pre-pack negotiations and will not favour the pre-packaged sale. Two important cases which discuss the grounds on which an administrator's appointment can be challenged in the context of a pre-pack have been discussed below.

\section{Challenging an administrator's appointment}

In Clydesdale v. Smailes ${ }^{201}$ the court had to decide on an application to replace the administrators in an administration proceeding. The facts of this case were similar to those of a typical pre-pack sale with the only difference being that the sale was affected upon the appointment of the administrator. In Clydesdale, the sale agreement stated that it would be complete on the appointment of an administrator and would be voided if no administrator was appointed. ${ }^{202}$ The creditors challenging the administrator's appointment noted that the administrator was involved in the pre-pack negotiations and had failed to consult the distressed firm's major creditors before entering into an agreement to sell the firm. Further, notice of the pre-pack was given only minutes before the administrator was appointed (thus commencing administration). ${ }^{203}$ There was also a lack of transparency about how the sale price was arrived at, this was relevant because the proprietor of the firm who negotiated the sale was offered a well-paid position at the firm that was purchasing his distressed firm. All these factors convinced the court that there was a need for an independent inquiry into the sale, and that the administrator could not conduct such an independent inquiry because of his involvement in the negotiation of the sale.

\footnotetext{
${ }^{200}$ DKLL Solicitors v. Revenue and customs, [2007] EWHC 2067 (Ch); FINCH \& MiLmAN, supra note 2, at 378. ${ }^{201}$ Clydesdale Financial Services \& Ors. v. Robert Smailes \& Ors. [2009] EWHC1745 (Ch) (Westlaw).

${ }^{202} I d$. at 3.

${ }^{203} \mathrm{Id}$.
} 
The precedent set in Clydesdale was followed in Ve Vegas. Even in Ve Vegas, the creditors challenged the appointment of the administrator on the grounds that an independent inquiry into the sale was called for and that this could not be carried out by an administrator who had been involved in the pre-formal negotiations. Specifically, the creditors showed that there existed a case for investigation into the directors' conduct and whether they had committed a breach of duty. Normally, an administrator would carry out this investigation, but in this case (as in Clydesdale) the administrators had a conflict of interest as they were engaged in the preformal negotiations leading up to their appointment. ${ }^{204}$

The cases discussed above reveal that pre-packs can be challenged in the UK by challenging the appointment of an administrator, specifically with respect to their independence. In cases where the court has concluded that the administrator needs to be removed, it has not commented on the validity of the pre-pack itself. Rather, in these cases, the court agreed that an independent inquiry into the sale or the company's affairs was needed, the administrators having participated in the pre-pack negotiations could not carry out this independent review. The court should consider the wishes of the majority creditors when deciding whether to remove an administrator but it will not be bound by what the creditors consider appropriate. ${ }^{205}$ In the absence of such accusations as those casted in Smailes and Ve Vegas, the merits of a pre-pack and whether it is the appropriate decision in a particular case will be left to the administrator's discretion. ${ }^{206}$

\section{Judicial treatment of pre-packs in the US}

Much like Chapter 11 pre-pack disclosures, the judicial treatment of Chapter 11 pre-packs is governed by the same provisions as regular Chapter 11 plans. The US Bankruptcy Court has the ability to scrutinize a plan and satisfy itself that it meets the requirements of section 1129 . The bankruptcy court has the ability to designate or void a plan's division of creditors into classes if the same has been done to manufacture a consensus without having regard for the characteristics of the creditors in each class. This practice has been referred to as 'gerrymandering' and eschewed by bankruptcy courts. Overall, the judicial standards applied to regular Chapter 11 plans are retained even when a bankruptcy court is presented with a

\footnotetext{
${ }^{204}$ Ve vegas Investors \& Ors. v. Henry Shinners \& Ors. [2018] EWHC 186 (Ch).

${ }^{205}$ Sisu Capital Fund Ltd. v. Tucker [2006] BCC 463. See Ve Vegas supra, at 10.

${ }^{206}$ Hellas Telecommunications, supra note 128.
} 
Chapter 11 pre-pack. Section 363 sales, however, do not have any statutory guidelines for the judiciary to rely on. Unsurprisingly, the development of judicial standards for approving section 363 sales has been inconsistent across different courts in the US.

\section{Section 363 pre-pack sales}

The Second Circuit Court of Appeal in In Re Lionel ${ }^{207}$ had to decide whether Lionel Corp. could sell its 82 percent share in Dale (amounting to one third of Lionel's assets). Unlike Lionel, Dale was not subject to bankruptcy proceedings, and its business (manufacturing electronic components) was relatively resilient in the face of market fluctuations. ${ }^{208}$ acknowledged that a literal reading of section 363 would effectively by-pass the reorganisation scheme under Chapter 11 of the US Bankruptcy Code. The Court of Appeal concluded that there was no risk of the value of Dale's stock diminishing in the absence of the sale. ${ }^{209}$ The court used precedent to hold that some form of urgency needed to be established in order to permit a sale of a large chunk of the debtor's assets before a reorganisation plan is confirmed. In addition to the likely change to the asset's value in the future (which is a very important factor), the court held that bankruptcy judges must consider the proportional value of the asset to the rest of the estate, the probability of a reorganisation plan being confirmed in the future, and the time that has elapsed since the bankruptcy petition was filed. These factors were suggested as guidelines and not an exhaustive list but they clearly show that 363 proceedings should not be an alternative to ordinary process of reorganisation under Chapter 11 of the US Bankruptcy Code. Applying these guidelines to the facts of Lionel the court of appeals held that there was no business justification to sell the Lionel's share in Dale - Dale's price was increasing, there was no urgent need to sell the stock to preserve its value, and the stock was being sold at an undervalue. ${ }^{210}$

Bankruptcy courts have also developed protections to ensure that section 363 sales do not predetermine the design of the actual Chapter 11 reorganisation plan. In Branifff Airways Inc. ${ }^{211}$ the Fifth Circuit Court of Appeal held that a sale of all of the debtor company's assets was impermissible. The court identified the following issues with the transaction that made it

\footnotetext{
${ }^{207}$ In re Lionel Corp 732 F.2d (1983)

${ }^{208} I d$.

${ }^{209} I d$.

${ }^{210}$ Id. at $1071-1072$

211700 F.2d. 935 (5 $5^{\text {th }}$ Circuit 1983)
} 
untenable. Part of the sale consideration was reserved only for the debtor's employees, shareholders, and (to some extent) unsecured creditors. This effectively dictated the terms of a future reorganisation plan which could not be allowed. ${ }^{212}$ The transaction also prevented creditors from exercising their Chapter 11 voting rights, and altered creditors' rights by releasing the debtor of claims against it. ${ }^{213}$ The court noted of these conditions went beyond the ambit of a mere 'sale' of Braniff's assets. ${ }^{214}$ Transactions (such as the one in Braniff) which effectively decide the direction of Chapter 11 proceedings or effect a reorganisation plan through section 363 are considered to be sub rosa ${ }^{215}$ and thus impermissible.

The cases discussed above attempted to preserve the Chapter 11 reorganisation process and set guidelines for when sales under section 363 would be permissible. However, these guidelines have not been strictly adhered to by subsequent decisions. For instance, the case of $\operatorname{In} R e$ Chrysler ${ }^{216}$ permitted the sale of substantially all of Chrysler's assets to another company through section 363. While the court referred to the Lionel standard in Chrysler, scholars have remarked that a diluted version of these standards were applied. ${ }^{217}$ There was also a sub rosa issue as some lien holders (funds overseeing the investment of retirement assets) received only a third of the value of their claims as a result of the sale and their collateral was transferred to the purchasing company. It is unlikely that the lien holders would have actually voted to approve a plan with these terms under Chapter $11 .^{218}$ However, since the sale was designed under section 363 there was no need for a vote, once the court approved the sale it was binding on all claimants. The court ultimately held that the plan was not sub rosa because the purchaser (Fiat) was paying a fair price for Chrysler's assets. Fiat's offer (USD 2 billion) exceeded the liquidation value of the Chrysler (USB 800 million). The focus of the sub rosa analysis in Chrysler was not on the procedural implication of the sale and how it effectively reorganised the corporation. Rather, the court emphasised on the attractiveness of the plan given that there were no alternative purchasers and that the price was fair. ${ }^{219}$

\footnotetext{
${ }^{212}$ Id. XIE, supra note 7, at 212-213.

213 XIE, supra note 7, at 212-213.

${ }^{214} I d$.

${ }^{215}$ Sub rosa is a Latin phrase. In the context of section 363, it refers to transactions that are not public and are carried out in secrecy. See XIE, supra note 7, at 211 (footnote 23 therein).

${ }^{216}$ Indiana State Police Pension Trust v. Chrysler 405 B.R. 84 (2009)

217 XIE, supra note 7, at 217.

${ }^{218}$ Korres, supra note 165 , at 966

${ }^{219}$ XIE, supra note 7, at 216.
} 


\section{DEVELOPING A PRE-PACK FRAMEWORK FOR INDIA}

The trade-off in a pre-pack is that the insolvency procedure is reduced to a conduit for the preformal negotiations. It effectively by-passes the mechanisms in insolvency procedures designed to ensure information dissemination and a fair opportunity for creditors to voice their concerns and vote. ${ }^{220}$ Pre-packs may also reduce the competitiveness of plans as they are inadequately tested by the market. ${ }^{221}$ The lack of publicity, which is a benefit of the pre-pack, militates against inviting multiple offers and carrying any public marketing of the plan. ${ }^{222}$ Employees, unsecured creditors, individual bond holders etc. are more likely to get steamrolled in pre-packs. ${ }^{223}$ The interests of these stakeholders have been woven into insolvency regimes across the world due to the recognition that the costs of insolvency are not bourn solely the company's creditors. ${ }^{224}$ However, section 363 and Schedule B1 style pre-packs in the US and the UK tend to ignore those who do not have strong pre-insolvency rights against the debtor. ${ }^{225}$ It has been argued that pre-packs which retain creditor protections or require court approvals are not pre-packs in the true sense as they are deny parties the benefits of a quickly executed sale. However, this is a very conservative view; as already indicated, pre-packs exist on a spectrum and so do their benefits. The speed offered by a pre-pack is usually inversely proportional to the protections retained for smaller creditors. Chapter 11 proceedings in the US thus are pre-packs even though they are very different from the pre-packs sales seen under section 363 and Schedule B1 in the UK.

\section{A. Choosing a pre-pack route}

The pre-pack regimes under Schedule B1 of UK and Section 363 of US are attractive options for India because they enable quick resolutions without having to solicit creditor approval for a plan. As already discussed, the IBC does not empower the resolution professional to sell a corporate debtor's assets. ${ }^{226}$ Nonetheless, Parliament is at the liberty to change this and enhance

\footnotetext{
${ }^{220}$ Neil Devaney, A Step in the Wrong Direction - UK and US Regulators Must Turn Their Attention to the Rise of Pre-Packaged Insolvencies, 26 INT'L FIN. L. REV. 26, 26 (2007).

${ }^{221}$ Graham Report, surpa note 9, $1 \uparrow$ 6.2, 7.5; FINCH \& MiLmAN, supra note 2, at 378.

${ }^{222}$ XIE, supra note 7, at 96-97.

${ }^{223}$ FINCH \& Milman, supra note 2, at 378-379; Walton, supra note 9, at 87.

${ }^{224}$ XIE, supra note 7, at 10-11, Elizabeth Warren, Bankruptcy Policy, 54 THE U. Of CHI. L. REV. 775, 789-90 (1987).

225 See, Finch \& Milman, supra note 2, at 379, 407; Korres, supra note 165, at 961.

${ }^{226}$ Singh, supra note 46, at 1; Vinod Kothari \& Sikha Bansal, Role of Insolvency Professionals, VINOD KOTHARI 69, http://vinodkothari.com/wp-content/uploads/2019/06/Role-of-IP-in-CIRP.pdf.
} 
the powers of the resolution professional to include the sale of a corporate debtor's assets. This would facilitate the 'spontaneous' evolution of pre-packs in India. While this is one viable option to introduce pre-packs, we view, it may be better for India to introduce pre-packs by providing a 'pre-pack track' under the IBC. This would be similar to the US Bankruptcy Code which has made provisions to allow a debtor to negotiate and solicit approval for a plan before they file for Chapter 11 reorganisation. It has the added benefit of doing away with the need to define a pre-pack, something which has proven difficult given the spectrum of agreements and transactions which can be considered pre-packs. ${ }^{227}$

Affording legislative recognition to pre-packs will give law makers the ability to decide how pre-packs interact with the rest of India's insolvency regime. The Supreme Court has tenaciously upheld the financial creditor's right to file an insolvency application upon a default notwithstanding any prior agreement with the debtor. While such an application of the IBC has provided certainty to financial creditors, it has the potential to derail the formal part of the prepack process. It's important to remember that a pre-pack is often negotiated after a default has occurred. In case a majority of creditors agree to the pre-pack and decide to file formal insolvency proceedings under the pre-pack route, law makers should ensure that the regular insolvency resolution route is no longer open to other creditors. The Supreme Court has strictly interpreted the provisions of the IBC and allowed a financial creditor to file an insolvency application against a debtor, even if the debt is disputed or if it is alleged that the creditor has not fulfilled their obligations towards the debtor. ${ }^{228}$ The moratorium of the pre-pack should be explicitly extended to cover any invocation of the regular insolvency resolution proceedings under the IBC, ${ }^{229}$ this will avoid multiple insolvency applications against the same debtor.

\section{B. Setting up a robust disclosure regime}

Transparency and adequate disclosure are important in maintaining the fairness of pre-packs. While they have limitations when functioning on their own and on a voluntary basis, they can work well if given statutory force. From the experience of the UK and the US, we find that the effectiveness of this transparency requirements is contingent on being able to affix post facto liability to insolvency professionals based on violations of transparency requirements. ${ }^{230}$ In

\footnotetext{
${ }^{227}$ XIE, supra note 7, at 142; FINCH \& MiLMAN, supra note 2, at 400-01; Finch, surpa note 90, at 13-14.

${ }^{228}$ Innoventive Industries v. ICICI Bank (2018) 1 SCC 407, ๆ 8.

${ }^{229}$ See Singh, supra note 46, at 10.

${ }^{230}$ XIE, supra note 7, at 133. See Re Hellas Telecommunications, supra note 128.
} 
the UK, SIP-16 has increased the amount of information available to creditors about a prepack. However, the route to actually hold an administrator accountable for their decisions remains tenuous. One of the reasons transparency measures have not achieved the desired results in changing the conduct of administrators is that these requirements are not statutory in nature. ${ }^{231}$ This is different from the position in the US where Chapter 11 requires adequate disclosures to be provided to creditors when obtaining their approval, even in a pre-pack. Not meeting this requirement will require the debtor to re-solicit votes after providing adequate disclosure.

In the UK, any breach in transparency requirements will not affect the validity of the pre-pack, though it can be the basis on which the UK Insolvency Service carries out disciplinary proceedings against the administrator. ${ }^{232}$ However, the fines imposed by the Insolvency Service have proven to be inadequate to deter administrators in repeating their problematic conduct. ${ }^{233}$ Violating professional standards (such as the SIP-16) is also not the sole basis on which an administrator is removed from a case, but it can be considered by the court when deciding on a petition for the administrator's removal. ${ }^{234}$ Were transparency requirements embedded in statute in the UK, harsher penalties could be imposed on erring administrators, presumably increasing compliance. ${ }^{235}$ A suggestion to this effect has been made in the UK but has been met with difficulties. ${ }^{236}$ Since there is no definition of a pre-pack, there will be ambiguity involved in determining which situations administrators ought to have complied with pre-pack disclosure requirements. ${ }^{237}$

Since pre-packs have not evolved in the present Indian framework and will need some sort of statutory sanction. Disclosure requirements for what are considered pre-packs can be added to existing rules or enacted as new ones. Having a robust transparency framework in India

\footnotetext{
${ }^{231}$ XIE, supra note 7, at 141-142; The Insolvency Service, Consultation/Call for Evidence: Improving the Transparency of, and Confidence in, Pre-packaged Sales in Administrations, BRITISH PRINT, 3, 6, (Mar. 2010), http://www.britishprint.com/downloads/managed/industry info/Pre-pack consultation document - Final.pdf [Henceforth Insolvency Service Consultation]; Vanessa Finch, Corporate Rescue: A Game of Three Halves, 32 LEGAL STUD. 302, 315-16 (2012).

232 XIE, supra note 7, at 142.

233 Id.

${ }^{234}$ Clydesdale Financial Services, supra note 201; Finch, supra note 90, at 11.

${ }^{235} \mathrm{XIE}$, supra note 7 , at 142

${ }^{236}$ See e.g. Consultation/Call for evidence on improving the transparency of, and confidence in, pre-packaged sales in administrations - RESPONSE OF INSOLVENCY LAWYERS' ASSOCIATION, 7, https://www.ilauk.com/docs/pre-pack_consultation_ila_response.pdf.

${ }^{237}$ Id.; Finch, supra note 90, at 13-14.
} 
alongside the introduction of pre-packs would go a long way to ensure that unsecured creditors are appraised of the pre-packs rationale and can make an informed decision about perusing litigation against it. The Government should combine the stability afforded by statutory recognition of pre-packs in the US with the salutary disclosure requirements in the UK's SIP16.

Giving pre-pack related disclosures statutory force will have another significant implication. Non-adherence to these requirements will have a bearing on the validity of the pre-pack itself. Parliament can decide on the seriousness it wants to afford to a breach of disclosure requirements. We suggest that the imposition of punishment on the resolution professional for non-adherence can be left to the professional body in charge of regulating them. Having clear disclosure requirements in the law will also assist the courts in unburdening towards developing standards (which risk being subjective) for what comprises adequate disclosures to creditors during informal pre-pack negotiations.

\section{Protection of creditors rights and the limits of judicial oversight}

On the question of creditor's rights, India can choose to retain the existing protections afforded to creditors. This would include the 66 percent approval threshold for a plan and the requirement that operational creditors are paid at least what they would receive in the event of a liquidation. The government may consider relaxing notice requirements for creditors who are being paid in full under a plan. This is similar to the deemed approval of unimpaired creditors under Chapter 11 of the US Bankruptcy Code. ${ }^{238}$

The IBC's limitation of voting rights to financial creditors reduces the number of votes a corporate debtor would have to solicit for a pre-pack. In the UK, one of the concerns relating to pre-packs is that it operates harshly against trade creditors (operational creditors in India). Even in the status quo, the IBC does not require operational creditors to approve the plan. As a compromise for operational creditors' exclusion from the voting process, the $\mathrm{CoC}$ and the NCLT need to ensure that operational creditors get a minimum amount under the resolution plan (equivalent to the sum they would have gotten in case of liquidation or if the purchase money were distributed per the liquidation waterfall). The pre-pack legislation should strongly consider retaining the protection given to operational creditors in the present IBC, this will

${ }^{238}$ Singh, supra note 46 , at 13. 
ensure that they are treated fairly and reduce the number of votes a plan will need in order to be approved. When it comes to court approvals, the NCLT can grant approvals to pre-packs as it does to a regular resolution plan. The criteria for rejecting a pre-pack must be laid down in a legislation and strictly followed by the NCLT. Importantly, the NCLT cannot continue its past trend of rejecting a plan and directing the $\mathrm{CoC}$ to consider another bidder's plan because it believes that a better deal can be achieved.

In the Binani Cements case ${ }^{239}$ the NCLT rejected resolution plan despite the fact that it was approved by 99.43 percent of the CoC. 10 percent of the $\mathrm{CoC}$ (votes of the Export Import Bank) who had approved the plan said that they had been forced to vote in favour of the plan, the alternative being that they would have only received the liquidation value of their claim. The proposed repayment of the Export Import Bank's dues under the plan accounted for 73 percent of its claims, most of the other creditors were being paid in full. The bidder's reason for not paying the Bank in full was that the corporate debtor was a guarantor for a principle borrower which was a non-performing asset. The details of every claim have not been explained in the judgement which makes it difficult to assess the fairness of the first bidder's plan. However, the NCLT was not able to identify the provision of the IBC which the aforementioned distribution contravened. Even if the votes of the Export Import Bank were to be excluded, the plan still had the approval of 89.43 percent of the $\mathrm{CoC}$, well above the 66 percent majority required by the IBC. The main grievance of some creditors was that the plan discriminated against them while enriching other financial creditors. Taking this into account, the NCLT asked the $\mathrm{CoC}$ to consider the plan of another bidder (Ultratech Cements) which fully paid all the debts of Binani Cements and the NCLAT as Appellate Tribunal upheld this decision. In justifying the NCLT's decision and its own, the NCLAT held that the first plan went against the principles of the IBC. However, it was unable to point to the provision of the IBC that was violated. The NCLAT emphasised on the need to maximise the value of the debtor's assets and balance the interests of the all the claimholders.

From the Binani Cements case, it is unclear what payment arrangements other than full payment to all creditors would have amounted to a fair allocation of money under a resolution plan. In Essar Steel ${ }^{240}$, the Supreme Court has clarified that the NCLT's power to approve or

\footnotetext{
${ }^{239}$ Binani Cements v. Bank of Baroda AT (Insolvency) No. 82/2018, Binani Cements v. Bank of Baroda AT (Insolvency) No. 82/2018.

${ }^{240}$ Committee of Creditors of Essar Steel v. Satish Kumar Gupta (2019) SCC Online 1478.
} 
reject a resolution plan is to be exercised within the four walls of the relevant IBC provision. ${ }^{241}$ There was no residual equity jurisdiction that vested with the NCLT which could be used to question the decision of the CoC. In this case, secured financial creditors were being repaid 5\% of their debt under the approved resolution plan. ${ }^{242}$ The Supreme Court held that the CoC has the right to vote on how to distribute the proceeds of a resolution plan as long as it accounted for payments to operational creditors under Section 30 of the IBC.

As early as the introduction of the BLRC report, creditors' wisdom was relied on to make business decisions relating to a distressed company. To this extent, the notion of a 'fair' resolution may be misleading because one cannot be certain that a more equitable solution could not have been arrived at. But the question of what is a fair and equitable resolution will always have subjective responses which will be heavily influenced by the stakeholder answering the question. The role of the NCLT, as correctly pointed out by the Supreme Court in Essar, is to be satisfied of the fairness of a plan, but within the limitations conceived by the IBC. In the context of insolvency law, fairness is not an abstract standard which resolution plans must aspire to meet. Rather, it is achieved through a set of minimum protections that plans need to adhere to under the IBC, these protections include creditors voting rights, and minimum payments that are required to be made to operational creditors under a plan. The Supreme Court's decision in Essar Steel reiterates the limits of the NCLT's discretion while approving a plan. When it comes to the approval of pre-packs, the NCLT must be just as circumspect in using its judgement to override any decision of the CoC.

For pre-packs to be effective in India, the NCLT cannot use the existence of a better offer to reject a plan which has been approved by the CoC. By their nature, pre-packs are not extensively marketed. Pre-pack negotiations are meant to be discreet and are thus not announced to the public to invite bids. While a pre-pack can be marketed to multiple parties to invite bids, whether this actually happens depends on the approach taken by the parties involved. This is different from a formal insolvency process which is publicised allowing more bidders to put forth their proposals. The relative lack of marketing means that there may well be better bids in the market for the business of the distressed company. If the Government wants to avoid discrimination between larger and smaller creditors or secured and unsecured

\footnotetext{
${ }^{241}$ Id. 9ศ $3-4$.

${ }^{242} I d . \uparrow 50$.
} 
creditors in the pre-pack process, it must clearly state what would comprise this discrimination. It must set a threshold for minimum, non-negotiable creditor rights and allow any negotiation respecting these rights to prevail. In the Indian context, these non-negotiable rights could be in the form of (existing) minimum payments to operational creditors, and financial creditors' voting rights. Such a restrained approach will allow India to have a pre-pack regime governed by court approvals like the one in the US. This way, the NCLT can play an important role in ensuring that the rights guaranteed under India's pre-pack track are respected. Importantly, the NCLT must strongly adhere to the precedent set by the Supreme Court in Essar Steel and not regress to decisions which interfere with creditors decisions sans a statuary basis.

The flexibility in negotiations enjoyed by pre-packs is not without its criticisms. Most insolvency regimes grant a right to participation to those who have dues against the corporate debtor, these participation rights are undermined by the pre-pack process. Claimants who are going to be fully paid generally do not participate in the actual voting, they are simply deemed to approve the resolution plan. Essentially, those who are unaffected by the plan in terms of the dues they receive do not decide on whether or not it ought to be implemented. The people most vulnerable during insolvency proceedings are usually unsecured creditors, accordingly, they are usually the ones to vote on administration plans in the UK and Chapter 11 reorganisation plans in the US. Unfortunately, it is these unsecured creditors who are often left out of prepack negotiations in the UK and the US. Empirical evidence from the UK suggests that while unsecured creditors do not have worse outcomes in pre-packs than in regular administrations, secured creditors enjoy better results in pre-packs than regular administration proceedings. ${ }^{243}$ This suggests that while pre-packs may be good at maximising the value of the corporate debtor, the surplus is disproportionately enjoyed by secured creditors and company's incumbent management. ${ }^{244}$ Irrespective of the types of disclosures, protections, and regulations imposed on a pre-pack regime, it is unlikely that it will be the 'best' outcome for all creditors involved.

\section{Compromising on speed for more stability and fairness}

The pre-pack model proposed above for the Indian insolvency regime will not result in resolutions that are as quick as ones seen under section 363, Title 11. The Chrysler sale, for

\footnotetext{
${ }^{243}$ FINCH \& MiLMAN, supra note 2, at 379-80; Walton, supra note 9, at 87.

${ }^{244}$ FinCH \& MilmAN, supra note 2, at 379-80; Walton, supra note 9, at 87.
} 
instance, was completed in forty-two days. ${ }^{245}$ Opposition to regulating pre-packs in the UK has also relied on the effect regulations will have on the expeditiousness of pre-packs. ${ }^{246}$ However, the pre-pack model proposed above will still allow companies to spend shorter periods of time under the formal insolvency process than the current IBC regime. Importantly, the suggested pre-pack framework is likely to be fairer and afford similar protections to creditors as regular resolution plans. Further, this type of pre-pack framework will afford flexibility and discretion to a distressed corporation's negotiations. Some writers have suggested implementing a UKstyle regime for asset sales without $\mathrm{CoC}$ or court approval. ${ }^{247}$ While this will allow quicker pre-pack sales and can be justified in some cases, the UK and US have shown that the use of asset sales is likely to become a substitute for the regular insolvency resolution process. Section 363 in the US was never intended to be used as a route to pre-packing, but that is precisely what it has become. ${ }^{248}$ The section was originally inserted to ensure that any perishable items of the debtor could be sold during the insolvency process so that the value they represent is not lost. ${ }^{249}$ However, this is no longer the basis for section 363 sales as can be seen from the evolution of decisions from the Re Lionel to Re Chrylser. Further, the slow uptake of selfregulation as seen through the sub-optimal use of the pre-pack pool in the UK has increased calls for legislating on pre-packs, specifically connected party sales in the UK..$^{250}$

The UK's experience has shown that reputational penalties that self-regulation rely on are inadequate motivators for compliance. This is evidenced from the compliance rates of SIP-16, and the use of the pre-pack pool. ${ }^{251}$ Even the Graham report suggested that its suggestions should be legislated on if they are not implemented through the industry, it may be time for UK to consider legislating on at least one of the Graham Report's recommendations. ${ }^{252}$ Prepack tracks that retain procedural safeguards applicable to creditors do not need to rely on voluntary industrial regulation or even mandatory version of these regulations. For instance, if creditors go a say in deciding on the whether a pre-pack was approved, there would be no need

\footnotetext{
${ }^{245}$ XIE, supra note 7 , at 208.

${ }^{246}$ FINCH \& MiLman, supra note 2, at 400; Wellard \& Walton supra note 20, at 151-52. See Insolvency Service Consultation, supra note 226.

${ }^{247}$ Otihjya Sen et. al., Designing a Framework for Pre-Packaged Insolvency Resolution in India: Some Ideas for Reform, VIDHI LEGAL POLICY, 29-30, (Feb. 2020), https://vidhilegalpolicy.in/wpcontent/uploads/2020/02/Report-on-Pre-Packaged-Insolvency-Resolution.pdf.

${ }^{248}$ Korres, supra note 165 , at 960-61.

${ }^{249} I d$. at 964 .

${ }^{250}$ Bolanle Adebola, Case for Mandatory referrals to the pre-pack pool, 32 INSOLVENCY INT'L, 71, 77 (2019).

${ }^{251} I d$.

${ }^{252} I d$.
} 
to for a pre-pack pool of experts to certify the reasonableness of a pre-pack. Should India choose to, it can implement set up the machinery for such industrial regulation (such as the prepack pool in the UK), however, the fairness of the IBC's pre-pack provisions should not be dependent on self-regulation.

In the UK, companies have started using pre-packs to implement schemes of compromise with creditors. $^{253}$ Schemes of arrangement under the Indian Companies Act, $2013^{254}$ and UK Companies Act, $2006^{255}$ follow similar procedures. Under both regimes a compromise scheme needs to be noted upon by $75 \%$ of the class of creditors with whom the compromise is being affected. ${ }^{256}$ When the process of debt restructuring is routed through a pre-pack administration in the UK, there is no need to get the $75 \%$ majority approval from creditors. UK Courts have allowed this practice, following their deferential approach when it comes to commercial decisions. $^{257}$

The use of pre-packs to effect debt structuring is an emblematic of the unpredictable nature of the use of broad powers to sell business assets. Pre-packs in the UK (and section 363) were not a result of a deliberate policy decision, rather, they were a product of legal creativity and business ingenuity. ${ }^{258}$ This type of ingenuity should be encouraged as it often guides informs legislation by articulating the needs of commerce. However, its unpredictable nature should undermine the objectives of insolvency regimes either. This is why we have proposed an approach that is safeguard-oriented. Ideally, the pre-pack track should be introduced with clear and effective safeguards in the form of creditors' procedural rights, disclosures etc. as discussed above. This helps create a fairer environment for pre-packs and the government and judiciary should not interfere with business decisions unless any of these safeguards are violated. While the pre-formal negotiations may take longer through this approach (as it does under Chapter 11 compared to section 363 in the US), the company will participate in formal insolvency proceedings for a shorter duration. If the NCLT adheres to the standards which are set out in the IBC for pre-packs, the process can be finished quickly and in time bound manner.

\footnotetext{
${ }^{253}$ Wijaya, supra note 174 , at 120.

${ }^{254}$ Companies Act, No 13, Acts of Parliament, 2013.

${ }^{255}$ Companies Act 2006, c. 46.

${ }^{256}$ Companies Act 2006, c. 46, § 899, Companies Act 2013, § 230(6).

257 Wijaya, supra note 174, at 127-28. See Re Christophorus 3 Limited [2014] EWHC 1162 (Ch).

${ }^{258}$ Vaccari, supra note 77, at 180; Wellard \& Walton, supra note 20, at 147.
} 


\section{CONCLUSION}

The meaningful question with regard of pre-packs is not how pre-packs can accommodate the interests of all creditors in the same way as a regular resolution process; they simply cannot. Some marketing has to be traded off in order to ensure a quick and quiet sale of the company. This is why the majority of the discussion in the UK and the US is anchored in providing adequate safeguards to creditors and bridging informational gaps. There are, however, important difference in the ease with which pre-packs can be regulated depending on the route through which they are introduced. Pre-packs that are introduced by empowering the insolvency professional or debtor to sell assets without creditors' approval have proven more challenging. Recent evidence has also shown that the can be used not only in the context of insolvency law, but more general debt restructuring. Further, conflicts of interest that arise through connected party sales begin to affect the efficacy of the insolvency process as creditor participation and inputs are eschewed.

The Indian government will need to approach the discussion on pre-packs after deciding which parts of the IBC are to remain non-negotiable even in pre-packs, and which parts can be substituted for a more flexible process. We recommend that it retains required creditor voting thresholds and protections given to operational creditors. There are of range of measures which can be implemented to increase the transparency and fairness of pre-packs. Law makers and the courts should be focused on determining the minimum required thresholds of fairness which need to be met and cannot be traded off for expediency and confidentiality. The IBC will also need to undergo broader changes with regards to its restrictions on connected parties' participation in the insolvency resolution process and its avoidance provisions. The focus should be on increasing the avenues and possible outcomes of pre-pack negotiations while strongly maintaining the protections granted in the IBC. The NCLT cannot continue to step in and find reasons to get a better deal for all creditors. Rather, they need to take a more restrictive approach and the law on pre-packs needs to clarify exactly which parameters would warrant a fair challenge to a pre-pack. 
